\title{
Review
}

\section{Artificial Intelligence Enabled Personalised Assistive Tools to Enhance Education of Children with Neurodevelopmental Disorders-A Review}

\author{
Prabal Datta Barua ${ }^{1,2}{ }^{-0}$, Jahmunah Vicnesh ${ }^{3}{ }^{(}$, Raj Gururajan ${ }^{1}$, Shu Lih Oh ${ }^{3}$, Elizabeth Palmer ${ }^{4,5}$, \\ Muhammad Mokhzaini Azizan ${ }^{6, *}$, , Nahrizul Adib Kadri ${ }^{7}$ and U. Rajendra Acharya ${ }^{3,8,9}$
}

check for updates

Citation: Barua, P.D.; Vicnesh, J.; Gururajan, R.; Oh, S.L.; Palmer, E.; Azizan, M.M.; Kadri, N.A.; Acharya, U.R. Artificial Intelligence Enabled Personalised Assistive Tools to Enhance Education of Children with Neurodevelopmental Disorders-A Review. Int. J. Environ. Res. Public Health 2022, 19, 1192. https:// doi.org/10.3390/ijerph19031192

Academic Editors: Massimo Esposito, Giuseppe De Pietro and Giovanni Luca Masala

Received: 7 December 2021

Accepted: 10 January 2022

Published: 21 January 2022

Publisher's Note: MDPI stays neutral with regard to jurisdictional claims in published maps and institutional affiliations.

Copyright: (c) 2022 by the authors. Licensee MDPI, Basel, Switzerland. This article is an open access article distributed under the terms and conditions of the Creative Commons Attribution (CC BY) license (https:// creativecommons.org/licenses/by/ $4.0 /)$.
1 School of Business, University of Southern Queensland, Springfield 4300, Australia Prabal.Barua@usq.edu.au (P.D.B.); Raj.Gururajan@usq.edu.au (R.G.)

2 Faculty of Engineering and Information Technology, University of Technology, Sydney 2007, Australia

3 Department of Electronics and Computer Engineering, Ngee Ann Polytechnic, Singapore 599489, Singapore; e0145834@u.nus.edu (J.V.); shulih@hotmail.com (S.L.O.); aru@np.edu.sg (U.R.A.)

4 School of Woman's and Children's Health, University of New South Wales, Sydney 2031, Australia; elizabeth.palmer@unsw.edu.au

5 Centre for Clinical Genetics, Sydney Children's Hospital, Randwick, New South Wales 2031, Australia

6 Faculty of Engineering and Built Environment, Universiti Sains Islam Malaysia, Bandar Baru Nilai, Nilai 71800, Malaysia

7 Department of Biomedical Engineering, Faculty of Engineering, University Malaya, Kuala Lumpur 50603, Malaysia; nahrizuladib@um.edu.my

8 School of Science and Technology, Singapore University of Social Sciences, Singapore 599494, Singapore

9 Department of Bioinformatics and Medical Engineering, Asia University, Taichung City 41354, Taiwan

* Correspondence: mokhzainiazizan@usim.edu.my

\begin{abstract}
Mental disorders (MDs) with onset in childhood or adolescence include neurodevelopmental disorders (NDDs) (intellectual disability and specific learning disabilities, such as dyslexia, attention deficit disorder (ADHD), and autism spectrum disorders (ASD)), as well as a broad range of mental health disorders (MHDs), including anxiety, depressive, stress-related and psychotic disorders. There is a high co-morbidity of NDDs and MHDs. Globally, there have been dramatic increases in the diagnosis of childhood-onset mental disorders, with a 2- to 3-fold rise in prevalence for several MHDs in the US over the past 20 years. Depending on the type of MD, children often grapple with social and communication deficits and difficulties adapting to changes in their environment, which can impact their ability to learn effectively. To improve outcomes for children, it is important to provide timely and effective interventions. This review summarises the range and effectiveness of AI-assisted tools, developed using machine learning models, which have been applied to address learning challenges in students with a range of NDDs. Our review summarises the evidence that AI tools can be successfully used to improve social interaction and supportive education. Based on the limitations of existing AI tools, we provide recommendations for the development of future AI tools with a focus on providing personalised learning for individuals with NDDs.
\end{abstract}

Keywords: neurodevelopmental disorders; mental disorders; personalisation; artificial intelligence; machine learning

\section{Introduction \\ 1.1. Mental Disorders}

Mental disorders with onset in childhood or adolescence, as encapsulated by the Diagnostic and Statistical Manual of Mental Disorders DSM-V, include both neurodevelopmental disorders (NDDs), such as intellectual disability; specific learning disabilities, such as dyslexia, attention deficit hyperactivity disorder (ADHD) and autism spectrum disorders (ASDs); and mental health disorders (MHDs), such as depressive, anxiety, stress 
related, conduct and psychotic disorders. Globally, childhood-onset mental disorders are becoming more prevalent, with a rate of 10-20\% [1]. NDDs are now recognised as a leading cause of morbidity in children, with a huge impact not only on the individual child, but also on their families and society [2]. There is also a possibility of the development of suicidal ideation in the aforementioned depressive [3], anxiety [4], stress-related [5], conduct [6] and psychotic disorders [4]. Moreover, there is frequent overlap between NDDs and MHDs. For example, between $30 \%$ and 50\% of children with ADHD are reported to have a comorbid MHD, such as depression [7,8], and over 70\% of children with ASD are reported to have a comorbid MHD, most commonly including anxiety $(40 \%)$ and ADHD $(30-40 \%)[9,10]$. The complex web of comorbidities between NDDs and MHDs can contribute to the severity of learning disabilities [11] in individual children and can further reduce the quality of life. This complex comorbidity can be associated with poorer long-term prognosis and has implications for tailoring treatments for individual children [12].

Both genetics and environmental factors contribute to the development of MDs in children. A child's neurological functioning and mental health can be influenced by the family's socioeconomic status, wherein poverty and low family income can affect the education, health and self-esteem of children, adversely affecting their growth, development and societal involvement. Furthermore, a parent's own poor health, mental disorder, social isolation or housing insecurity can diminish his/her capability of effectively parenting the child by providing a supportive environment for growth and development, which is necessary to keep mental health problems at bay [13].

Thus, childhood onset MDs in general, and NDDs specifically, have a huge impact on individuals, families and society, and there is a pressing need to understand how best to recognise and treat these conditions. This systematic review has two aims. First, to provide an overview of how AI technologies have been applied to assist students with the most common and impactful NDDs, namely ADHD, dyslexia and ASDs. Second, to highlight the limitations of existing developed AI tools to enable recommendations to be made for future directions in AI development, so that personalised education for these students can be improved further.

\subsubsection{ADHD}

The NDD ADHD, with prevalence reported between $9 \%$ and $40 \%$ [14], has multiple aetiologies wherein combinations of environmental and genetic aspects play a role in contributing to the pathogenesis and its diverse phenotypes [15]. Non-genetic risk factors have been suggested to include brain injury, premature delivery, maternal alcohol and tobacco use during pregnancy, and contact with certain environmental agents, such as lead, during pregnancy or at a young age [16-18]. Not uncommonly, children meeting diagnostic criteria for ADHD have other comorbidities, including oppositional defiant and conduct disorders (ODD and CDs) [19,20] and depressive and anxiety disorders [21], as well as specific learning disorders [22]. Children with ADHD have difficulties in maintaining sustained attention, can be hyperactive, fidget and find it difficult to participate in turn taking [17]. Preliminary research points to differences in brain volumes in children diagnosed with ADHD compared to neurotypical children, particularly affecting the frontal and parietal cortices (Figure 1).

\subsubsection{Dyslexia}

NDD dyslexia is a common type of learning disability, affecting 3 to $15 \%$ of school-age children [23]. Individuals with dyslexia have specific impairments in the development of expert reading skills. Dyslexia is characterised by difficulties with correct and/or fluent word recognition and poor spelling and decoding abilities [24]. Individuals with dyslexia have been shown to have differences in functional brain imaging compared to non-dyslexic individuals, for example, reduced neural adaptation to repetitive stimuli [25], as depicted in Figure 2. Children with dyslexia can have other specific learning deficits [24], low self-confidence, anxiety and depression. 
(a)

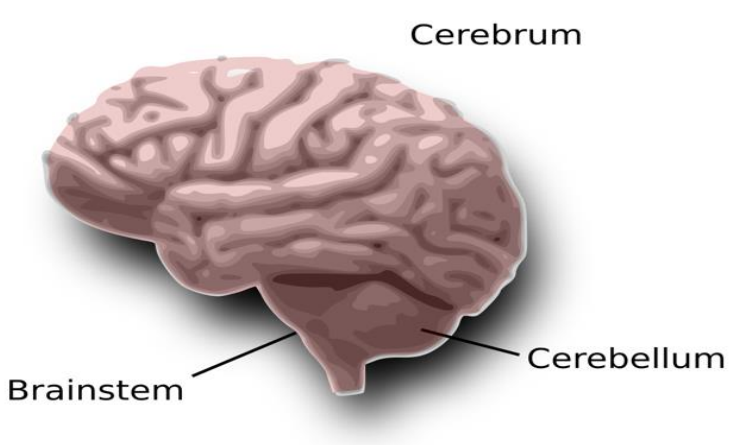

(b)

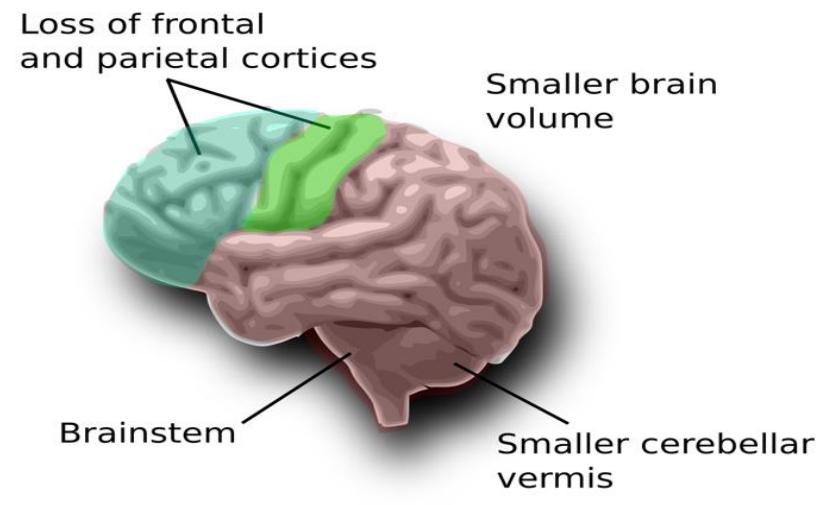

Figure 1. (a) Normal brain and (b) ADHD brain with smaller volume.

\section{Normal}

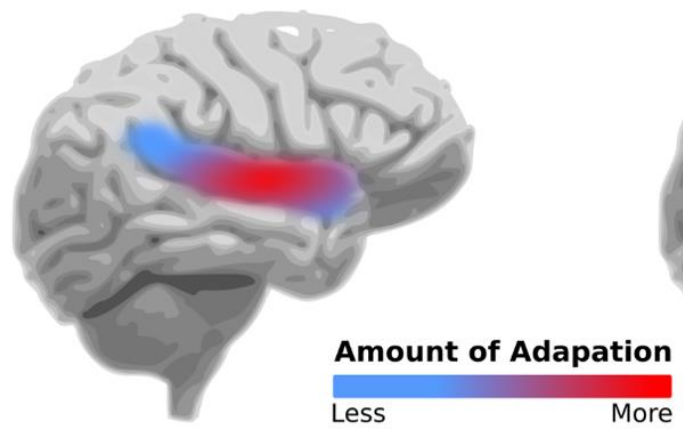

(a)
Dyslexia

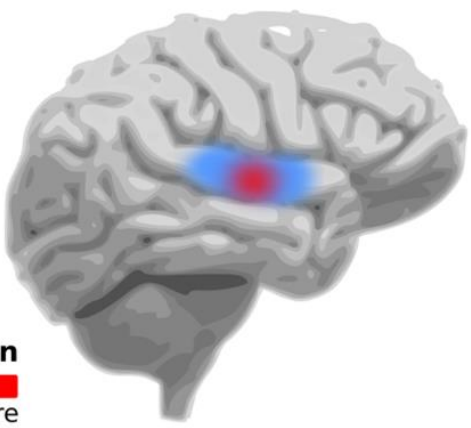

(b)

Figure 2. (a) Large neural adaptation in normal brain and (b) reduced neural adaptation in dyslexic brain.

\subsubsection{Autism Spectrum Disorders}

Autism spectrum disorders (ASDs), with a reported prevalence in developed countries of around $2 \%$ [26], typically present within the first three years of life. ASDs are characterised by challenges in social interaction $[27,28]$, speech and language delays, avoidance of eye contact, struggles to cope with changes in environment, the display of repetitive behaviours, and differences in learning profiles [26]. Children and adults with an ASD have a high frequency of anxiety and depression. Research into the pathophysiology of ASDs have revealed neurobiological differences between children with ASDs and those without ('neurotypical' children). Figure 3 highlights the excess neural connections between neurons in the brain of a child with an ASD compared to a neurotypical individual [29]. These excessive connections are thought to be secondary to reduced 'pruning' of damaged neuronal connections during brain development. This neuropathological difference is understood to result in disordered neural patterning across the brain and dysregulation in cognitive function coordination between different brain regions [30]. 


\section{Normal Brain}

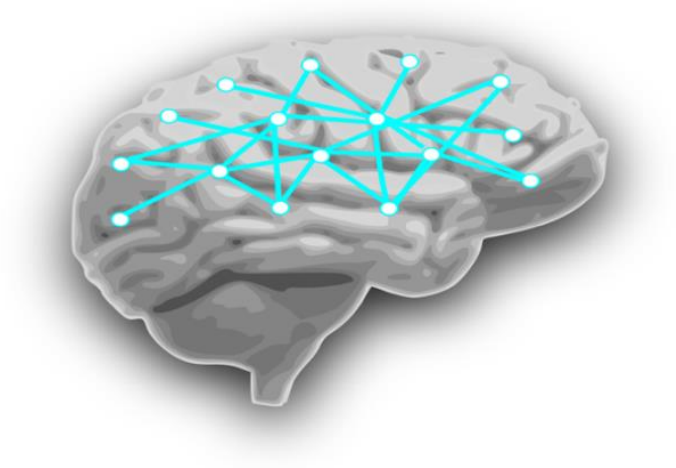

(a)

\section{Autistic Brain}

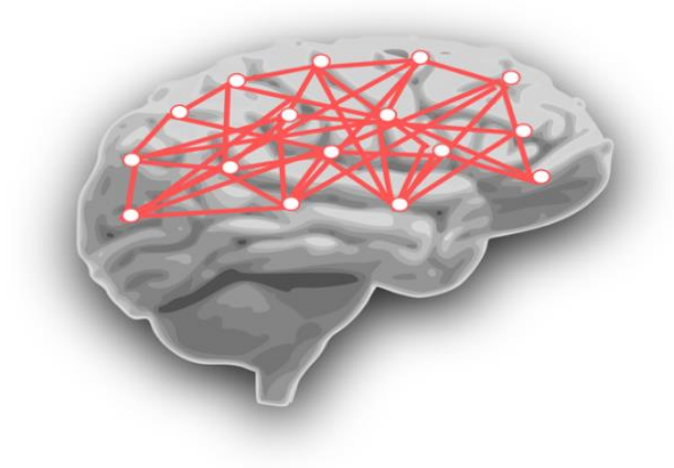

(b)

Figure 3. (a) Neurotypical brain and (b) ASD brain with denser neural connections.

\subsection{Personalised Assistive Tools Using Artificial Intelligence for Children with NDD}

The prior summary highlights that NDDs, such as ASDs, ADHD and dyslexia, are globally prevalent conditions associated with poor learning outcomes and a high prevalence of comorbid MHDs. A recent study attests that more support strategies are required to help students with these conditions in their learning in mainstream schools [31]. There is a critical need to apply effective tools to improve learning outcomes. Personalised assistive educational tools might help improve educational outcomes, helping affected individuals to integrate better into society, reducing stigma, isolation and stressful events, such as bullying, that are known to be common triggers for suicide attempts [32]. Hence, Section 1 highlights the three main NDDs and the need for personalised assistive tools. Section 2 discusses instructional practices employed in schools, challenges encountered and the potential role of AI tools in addressing those challenges. Section 3 discusses the research methodology, while Section 4 provides a summary of AI tools developed and discusses the effectiveness of these tools for personalised education. In Section 5, the limitations of existing AI tools are discussed. In Section 6, the future AI tool that addresses the limitations of existing tools for personalised education is proposed. Chapter 7 concludes the review study.

\section{Current Management Approaches for Children with NDD}

\subsection{Individualised Educational Approaches for a Child with ADHD}

Inclusive approaches are recommended so that students with NDD can be included in mainstream schools wherever possible [33]. However, mainstream classroom settings can worsen symptoms in children with ADHD, especially when students are expected to sit still, remain quiet and stay focused [34,35]. Mainstream schooling without additional support can thus damage children's self-esteem and negatively impact their relationships with teachers and peers [33]. Hence, to cater to the individual needs of these children, it is recommended that teachers employ individualised educational practices in the classroom $[36,37]$. Details of such individualised educational practices are listed in Table 1.

\subsection{Individualised Educational Approaches for Children with Dyslexia}

A multi-sensory approach, whereby information is shown simultaneously through varying channels, is reported to be preferable when teaching dyslexic children in schools [18]. Table 2 summarises strategies that have resulted in successful outcomes when employed in the school context for children with a diagnosis of dyslexia. 
Table 1. Individualised educational practices in schools for children with ADHD.

Learning Area

Reading comprehension

\section{Intervention}

Establish a sustained silent reading time daily.

Allow the child to read a book silently while listening to the teacher reading the story to the whole class.

Getting the child to make a storyboard, retell a story during story sessions, role-play characters in a favourite story.

Allowing the child to play board games/computer games to enhance reading comprehension skills.

Maintaining a word-bank book for words that are hard to read. Providing students with another set of books to be read at home [36]

Teaching children simple reminders on how to learn tougher phonics.

Teaching children how to recognise word families for phonetic concepts.

Phonics

Allowing students to play board games, such as Bingo or computer games, to enhance phonics.

Using picture-letter charts for children who can identify sounds but not letters [36]

Using storyboards to teach students to recognise parts of a story for writing. Creating a post-office in the classroom for students to write and receive letters from their

Writing teachers and peers.

Using tape recorders to dictate as an alternative to writing or having teacher/peer to write for students who would tell the story [36]

Aligning spelling words to frequently used words by children everyday.

Spelling

Partnering the child with another peer to encourage each other to quiz on spelling words. Using colour-coded letters to help students spell difficult words. Combining movement activities with spelling lessons [36]

Using special writing paper or teaching how to use a finger spacing to space out each word

Handwriting when writing.

Teaching handwriting skills through structured programmes [36]

Using mnemonics to describe fundamental steps easily for Maths computation.

Mathematics computation

Colour-coding arithmetic symbols to provide visual cues, allowing students to use calculators for basic computation, using computer/board games for practicing computations [36]

Table 2. Individualised educational practices in schools for children with dyslexia.

\section{Learning Area}

1. Failure in reading, grouping letters in words.

2. Phonology

3. Grammar

\section{Intervention}

Using visual perceptions, such as signage or touching letters, to help in reading. Providing simultaneous stimulation of each ear using different sounds [23]

Employing strategies that help phonological processing, such as 'minimal pairs,' 'common syllable words,' and 'vocal syllabification' [23]

Using grammatical processing strategies, such as 'syllabification,' 'declension of nouns,' 'stress,' and 'nouns' [23]

Using the syntactic approach to teach punctuation and sentences/paragraphs. Using the 'segmentation with highlighting' technique for sentence and text segmentation [23]

\subsection{Teaching Support in Schools for Students with ASDs}

Children with ASDs think, learn and behave differently from neurotypical children and differences in auditory processing, inspiration, emulation and organisation can hamper the learning success of children with ASD [38]. Hence, unique structured teaching strategies have been employed to cater to the different learning needs of ASD children, as listed in Table 3 [38]. 
Table 3. Individualised instructional practices in schools for children with ASD.

\begin{tabular}{|c|c|}
\hline Structured Teaching Strategies & Intervention \\
\hline Physical structure & $\begin{array}{l}\text { Establish a supportive classroom environment } \\
\text { by creating clear physical or visual boundaries } \\
\text { such that expected behaviours for each defined } \\
\text { space can be taught and reinforced [39] }\end{array}$ \\
\hline Reducing auditory and visual disturbances & $\begin{array}{l}\text { Too much auditory or visual stimuli may } \\
\text { hamper processing power; hence, unnecessary } \\
\text { distractions are removed in classrooms to help } \\
\text { students focus better on concepts taught [39] }\end{array}$ \\
\hline Visual schedules & $\begin{array}{l}\text { Implementing visual schedules for the day } \\
\text { (instead of using verbal probes), according to } \\
\text { the learning needs of each student to enhance } \\
\text { student independence and engagement during } \\
\text { lessons [39] }\end{array}$ \\
\hline Work system & $\begin{array}{c}\text { Implementing a work system for any type of } \\
\text { educational activity helps to organise the } \\
\text { student by providing a systematic work } \\
\text { routine [39] }\end{array}$ \\
\hline Visual structures & $\begin{array}{l}\text { Adding a physical or visual aspect to some } \\
\text { tasks to help students understand better how } \\
\text { an activity needs to be completed [39] }\end{array}$ \\
\hline
\end{tabular}

\subsection{Challenges in Implementing Individualised Learning Approaches in Schools}

Despite evidence that individualised lessons are effective in helping children overcome their learning disabilities, teachers face several challenges in achieving this goal [40]. It takes a lot of time for teachers to provide differentiated instructions, ensure the child has understood them, and then achieve goals that have been set for individual students [40]. Many schools have shortages of appropriate learning resources. Therefore, an assistive learning tool that can be personalised for children's individual learning challenges and needs would be very helpful for teachers and a great support in helping students meet their individual goals. Although learning a new tool and teaching children to learn the assistive tool may be time-consuming initially, the benefits of using such tools to support individualised learning and improve overall clinical and educational outcomes are clear.

\subsection{Use of Artificial Intelligence in Therapies and Supportive Education of Children with Mental Disorders}

\subsubsection{Conventional Methods Using AI}

Machine learning forms a part of artificial intelligence (AI) wherein the model is able to do tasks automatically, without needing any human interference. The conventional machine learning models are hence trained by the input data fed to them, after which these models are able to predict outcomes with high accuracies. Deep learning is a subfield of machine learning in which large data is used to train these models, which can also predict outcomes with high accuracies. Both models are commonly used in the diagnosis of some neurological disorders, such as autism [41,42], ADHD [43,44] and depression [45-47], with high accuracies. The models are either fed with images obtained from computerised tomography (CT), magnetic resonance imaging (MRI) and positron emission tomography (PET) scans or electroencephalogram (EEG) signals for the diagnosis of neurological disorders. Figure 4 shows the sequence of steps involved in training a machine learning model for diagnosis; after the input of signals or images, pre-processing takes place to clean the data, after which features are extracted and ranked thereafter, to obtain the most significant features, before they are finally classified into normal or abnormal classes. While the feature extraction and selection processes need to be done manually by the researcher for conventional models, these processes are done automatically in deep models. 


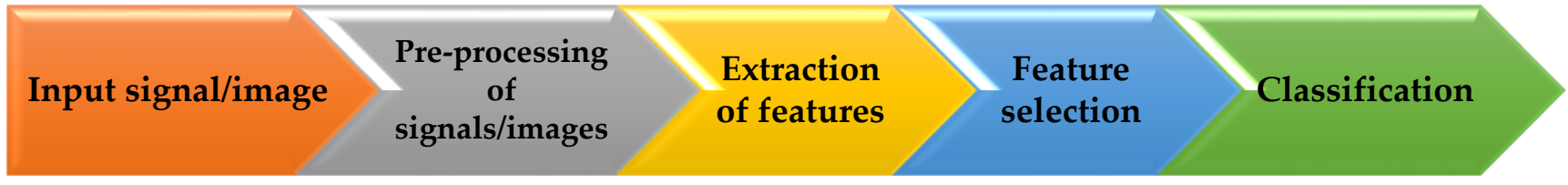

Figure 4. Sequence of steps for training a machine learning model.

\subsubsection{Advanced Methods Using AI}

Some frequently used deep models include the convolutional neural network (CNN) [48-50], long-short term memory model (LSTM) [51] and autoencoder [52], as depicted in Figures 5-7, respectively. In CNN models, the input data is fed to the convolution layer. New feature maps are created in each successive layer wherein more robust features are extracted for forecasting. In the final fully connected layer, the data is classified [48]. The LSTM encompasses three main blocks of memory cells, input, forget and output gates, which are accountable for controlling the information stored, read and written on the cell, respectively, as data comes in [51]. The LSTM principally performs by remembering important information from preceding states and building upon them [51]. Encoders are arranged to form the deeper autoencoder model. Autoencoders perform by encoding unlabelled input data and rebuilding the data accurately thereafter. These models comprise the coding and decoding phases, wherein the same weights are used to encode the feature and rebuild the output [52].

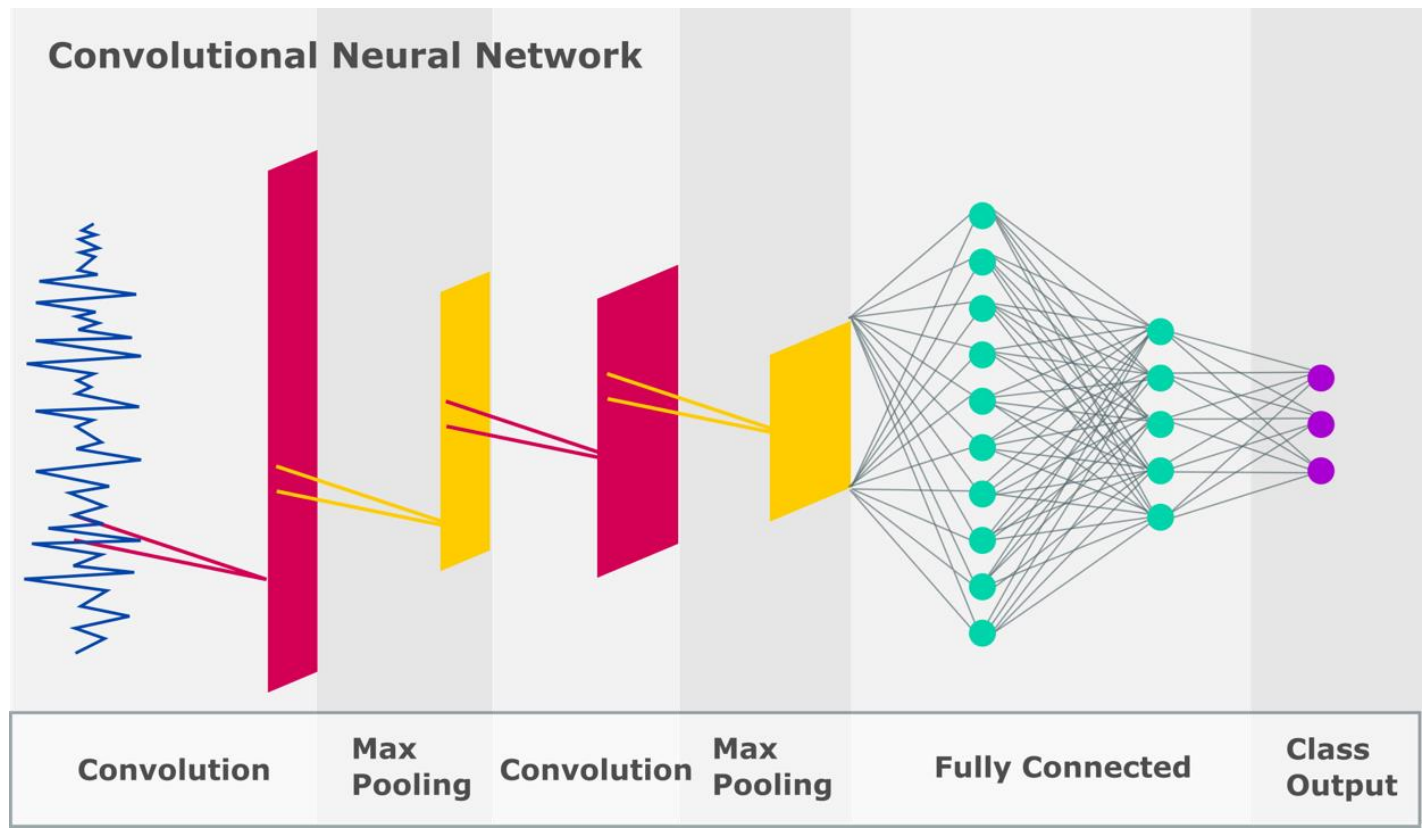

Figure 5. Illustration of the CNN model.

\subsubsection{Importance of AI in Therapies and Supportive Education}

AI has been used to assist in social skills training in children with ASDs to recognise and respond to social cues. Belpaeme et al. [53] used sensory features, such as facial expression, body movements and voice recordings, as inputs to a machine learning model (implemented in a robot) to analyse autistic children's behaviour and engagement levels for therapy. These input features were then combined with target outputs, engagement markers in this case, to train the model. The study proved the potential for the robot to adapt to its interactant, hence influencing engagement in participants. In another study, Sanghvi et al. [54] used postural expressions, such as silhouette images of the upper body, as they played chess with a robot to analyse the engagement levels of autistic children. Another positive outcome was established through this study; the potential of integrating 
representative data (as described above) with an affect recognition model to act as a game mate for autistic children in the real world. In a different study, Kim et al. [55] used audio recordings as input features to analyse the emotional states of autistic children. These features were fed to the support vector machine model, integrated with a robot, to assess their social engagement as they played with the robots. This enhanced audio-based emotion forecast approach discusses the possibility of sustaining a more natural interaction between autistic children and the robot, hence allowing the robot to assess the engagement level of the children more accurately and modify its responses to maintain an interactive learning environment. Other researchers have explored different input features, such as facial expressions [56], body movements [57], bio signals [58] and vocalisations [39]. In a more recent study, Esteban et al. [59] explored input features, such as facial expressions, direction of look, body posture and voice tones, to a model within the NAO robot to assess the social engagement of autistic children. This study attests to the capability of robots to possess increased autonomy, so as to lighten the load of therapists.

Moving towards individualisation, Rudovic et al. [60] developed a personalised deep model, using coordinated video recordings of head and body movements, facial expressions and gestures, audio recordings and bio signals such as heart rate, electrodermal activity and body temperature, to assess the engagement of autistic children. The results reported that the model matched human experts, the prediction of affect and engagement with that of human experts, with an accuracy of about $60 \%$, outperforming non-personalised machine learning solutions. In another study, a hybrid physical education teaching tool was developed, wherein speech recognition combined with artificial intelligence was used to construct a personalised voice interactive educational robot. The results showed that the robot was able to answer students' questions, achieving a recognition accuracy of more than $90 \%$ [60]. Hence, the aforementioned studies affirm that AI is a promising avenue to improve social interaction and supportive education in children with mental disorders.

\section{Long Short Term Memory}

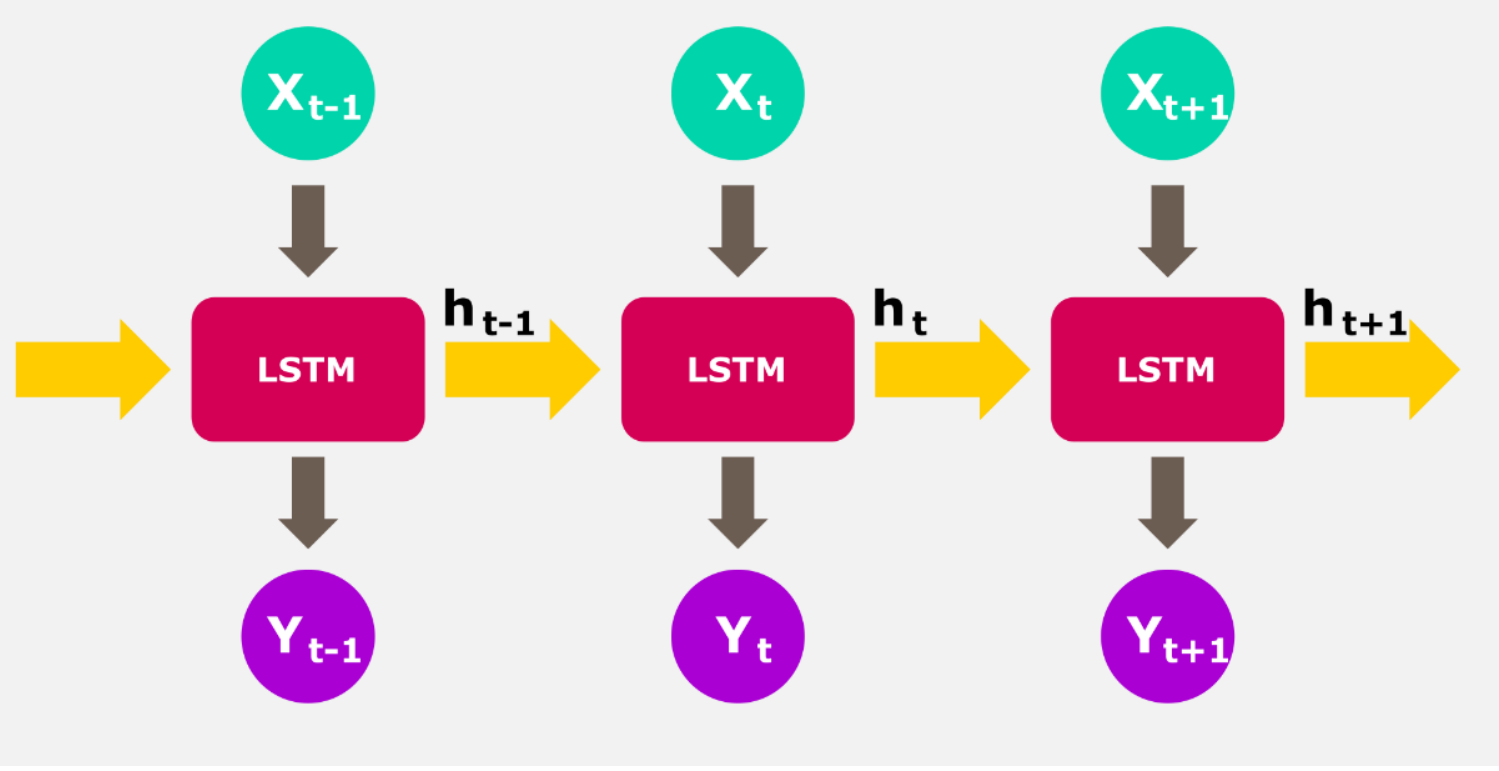

Figure 6. Illustration of the LSTM model. 


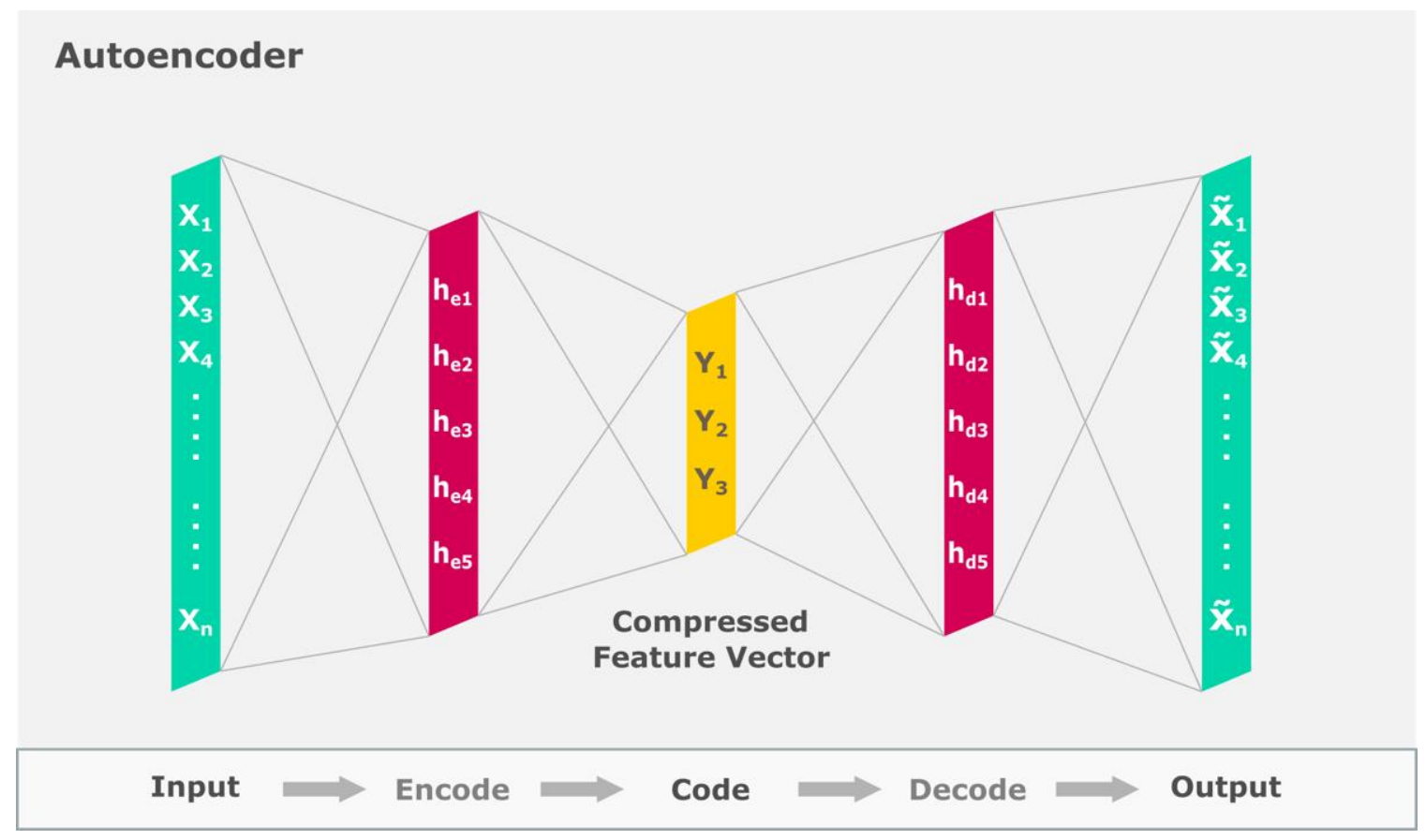

Figure 7. Illustration of the Autoencoder model.

\section{Materials and Methods}

The systematic review was conducted based on the Preferred Reporting Items for Systematic Reviews and Meta Analyses (PRISMA) guidelines to analyse the most relevant studies on assistive tools developed to address learning disabilities using machine learning models. The search was conducted between the years 2011 and 2021. The relevant journal articles were searched through the IEEE, Google Scholar, PubMed, Science Direct and Springer Link scientific repositories, as seen in Table 4. The Boolean search strings such as "machine learning," "artificial intelligence tools," "Autism spectrum disorder," "Attention deficit hyperactivity disorder," "dyslexia," "students" and "learning" were used in various combinations. The relevant articles were gleaned from the various databases for this review, based on three primary processes from the PRISMA guidelines. First, a total of 20,926 articles were identified based on the Boolean search strings for autism spectrum disorder, attention deficit hyperactivity disorder and dyslexia. From the IEEE, Google scholar, PubMed, Science Direct and Springer Link repositories, 1, 19, 800, 0, 445 and 680 articles were retrieved, respectively, wherein most articles described the diagnostics/prediction/screening of ASD, ADHD, dyslexia or other neurodevelopmental disorders. Subsequently, articles were screened wherein duplicate and irrelevant articles were excluded based on the inclusion and exclusion criteria. The process culminated with the selection of the most relevant articles, which was set to 26. The flowchart detailing the processes involved in the retrieval of appropriate articles using PRISMA guidelines is shown in Figure 8.

The search was conducted between February to March in 2021. Studies were included if they met the following criteria:

They described the use of AI tools to help students with ADHD, Dyslexia and/or ASD in their learning:

They were published between the years 2011 and 2021.

They were published in a peer-reviewed journal.

They were published in English.

Studies were excluded if:

They described the use of AI tools to help students with other disorders apart from the NDDs ADHD, dyslexia and/or ASD. 
The article was not published in English.

The article was not published in a peer-reviewed journal.

The article was published before 2011.

Table 4. Results of the Boolean search string for the respective repositories.

\begin{tabular}{|c|c|c|c|}
\hline \multicolumn{4}{|c|}{ Boolean Search String } \\
\hline Database & Title & $\begin{array}{c}\text { AND [Title/Abstract/ } \\
\text { Full Text] }\end{array}$ & No. of Articles \\
\hline IEEE & \multirow{5}{*}{$\begin{array}{l}\text { “Autism spectrum } \\
\text { disorder", AND/OR } \\
\text { "Attention deficit } \\
\text { hyperactivity } \\
\text { disorder" AND/OR } \\
\text { "dyslexia", Artificial } \\
\text { intelligence AND/OR } \\
\text { tools, students } \\
\text { AND/OR learning }\end{array}$} & \multirow{5}{*}{$\begin{array}{l}\text { Machine learning, } \\
\text { Neural networks, } \\
\text { deep learning }\end{array}$} & $\begin{array}{c}\text { Autism: } 0 \text {, ADHD: } 1 \text {, } \\
\text { Dyslexia: } 0\end{array}$ \\
\hline Google Scholar & & & $\begin{array}{l}\text { Autism: } 12100 \text {, } \\
\text { ADHD: } 3900, \\
\text { Dyslexia: } 3800\end{array}$ \\
\hline PubMed & & & $\begin{array}{c}\text { Autism: 0, ADHD: 0, } \\
\text { Dyslexia: } 0\end{array}$ \\
\hline Science Direct & & & $\begin{array}{c}\text { Autism: 176, ADHD: } \\
\text { 172, Dyslexia: } 97\end{array}$ \\
\hline Springer Link & & & $\begin{array}{l}\text { Autism: 357, ADHD: } \\
\text { 179, Dyslexia: } 144\end{array}$ \\
\hline
\end{tabular}

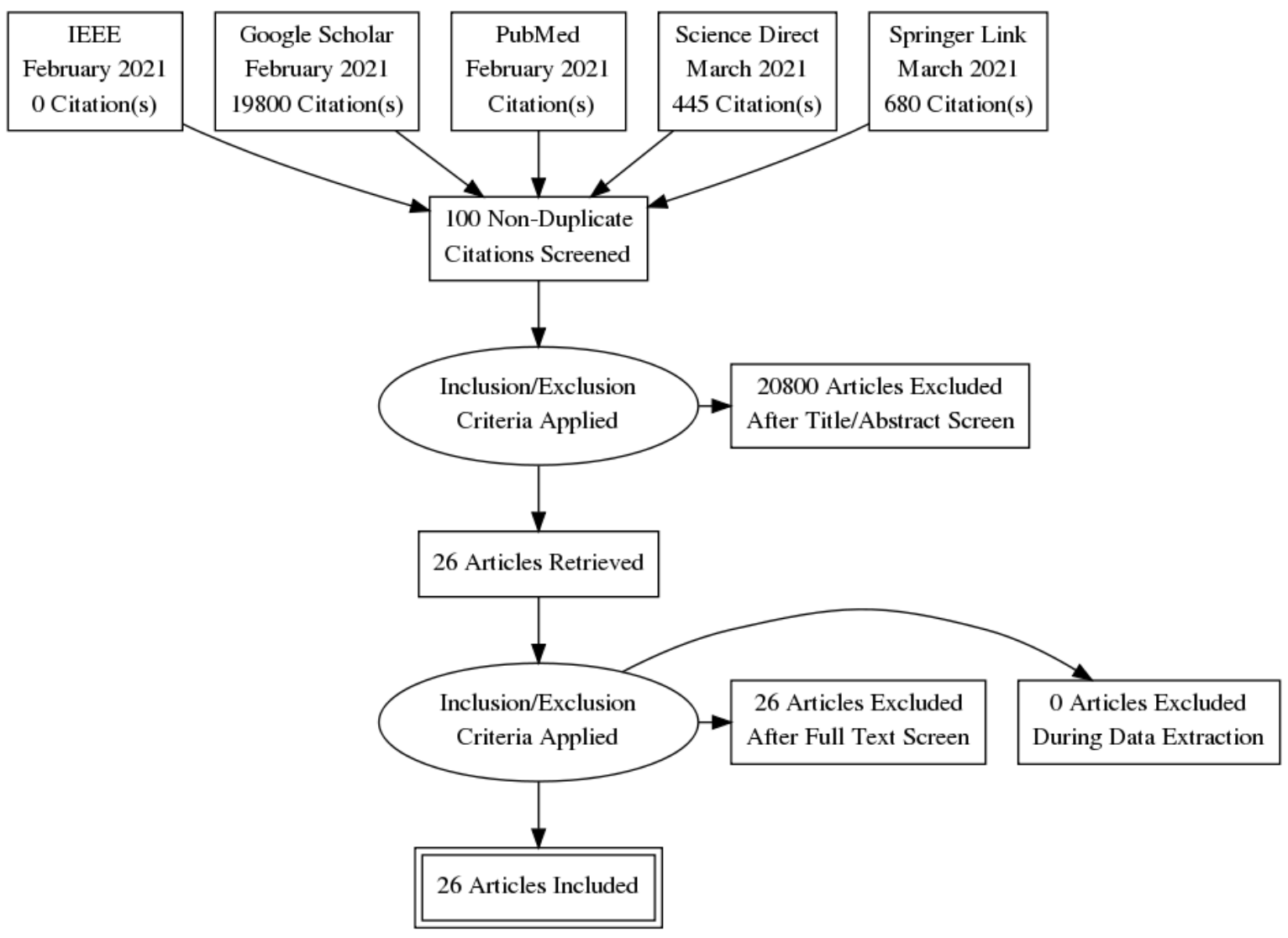

Figure 8. Flowchart detailing the use of PRISMA guidelines for selection of relevant articles.

\section{Results}

\subsection{Summary of Articles Collated}

Table 5 presents the summary of articles that involve the use of AI tools (machine learning techniques) for teaching children with learning disabilities. Abstracts were first searched and then a full text review was conducted to ensure that the studies met the 
inclusion and exclusion criteria and that data could be extracted on the AI tool used, the features/model used for training, the type of technology and the learning area addressed (Table 5). Although not commonly reported, the effectiveness of any AI tools on students' learning was also recorded.

Table 5. Review of AI assistive tools used to address learning disabilities of students with NDDs.

\begin{tabular}{|c|c|c|c|c|c|}
\hline Author/Year & AI Tool & $\begin{array}{l}\text { Features/Model Used } \\
\text { for Training }\end{array}$ & $\begin{array}{c}\text { Type of } \\
\text { Technology }\end{array}$ & $\begin{array}{l}\text { Learning Area } \\
\text { Addressed }\end{array}$ & Effectiveness \\
\hline \multicolumn{6}{|c|}{ AI Assistive Tools Used to Teach Students with ADHD. } \\
\hline 2014 [61] & KAR robot & - & $\begin{array}{l}\text { Assistive } \\
\text { technology }\end{array}$ & $\begin{array}{l}\text { Improve social } \\
\text { skills via } \\
\text { storytelling. }\end{array}$ & $\begin{array}{l}\text { Improves } \\
\text { children's } \\
\text { cognitive } \\
\text { performance. }\end{array}$ \\
\hline 2015 [62] & $\begin{array}{l}\text { Child activity } \\
\text { sensing and } \\
\text { training tool }\end{array}$ & $\begin{array}{l}\text { - } 42 \text { features } \\
\text { (users' physical } \\
\text { and } \\
\text { physiological) } \\
\text { - Machine } \\
\text { learning } \\
\text { algorithm (not } \\
\text { specified) }\end{array}$ & $\begin{array}{l}\text { Real time assistive } \\
\text { technology }\end{array}$ & $\begin{array}{l}\text { Real-time assistive } \\
\text { tool that tracks } \\
\text { activities and helps } \\
\text { students } \\
\text { sustain attention. }\end{array}$ & $\begin{array}{l}\text { An assistive } \\
\text { intervention that is } \\
\text { based on a } \\
\text { smartphone and } \\
\text { has the potential to } \\
\text { aid a child with } \\
\text { ADHD who has } \\
\text { lost focus in } \\
\text { his/her work. }\end{array}$ \\
\hline $2018[63,64]$ & $\begin{array}{l}\text { WatchMinder } \\
\text { vibrating watch }\end{array}$ & 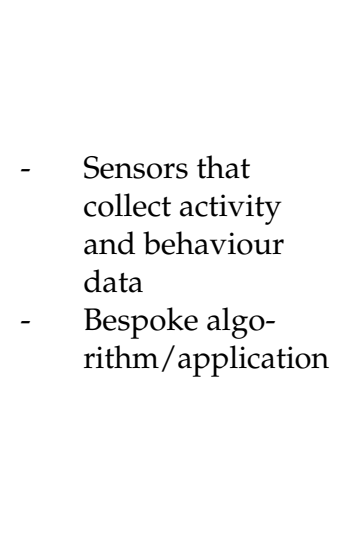 & $\begin{array}{l}\text { Wearable } \\
\text { technology }\end{array}$ & $\begin{array}{l}\text { Helps to send } \\
\text { constant reminders } \\
\text { to students to } \\
\text { refocus on } \\
\text { their work. }\end{array}$ & $\begin{array}{l}\text { The watch has } \\
\text { been effective as a } \\
\text { simple memory } \\
\text { aid for ADHD } \\
\text { children with the } \\
\text { auditory or } \\
\text { vibrating alarm } \\
\text { feature. The watch } \\
\text { has been found to } \\
\text { be affordable, } \\
\text { durable, } \\
\text { dependable and } \\
\text { effective by } \\
\text { users [65] }\end{array}$ \\
\hline 2018 [63] & $\begin{array}{c}\text { Speech recognition } \\
\text { software (Dragon } \\
\text { Naturallyspeak- } \\
\text { ing(Dragon Sytems } \\
\text { company, United } \\
\text { States, version 15, } \\
\text { /Voice } \\
\text { Finger/ViaTalk } \\
\text { (LLC Company, } \\
\text { New York/Tazti } \\
\text { (Voice Tech Group } \\
\text { company, } \\
\text { United States) }\end{array}$ & $\begin{array}{ll}\text { - } & \text { Audio data } \\
\text { - } & \text { Deep learning } \\
\text { models (spectro- } \\
\text { grams / filter } \\
\text { banks [66] }\end{array}$ & $\begin{array}{l}\text { Assistive } \\
\text { technology }\end{array}$ & $\begin{array}{l}\text { Replaces writing } \\
\text { activity with } \\
\text { speech to allow } \\
\text { students to express } \\
\text { themselves } \\
\text { efficiently without } \\
\text { tiring themselves }\end{array}$ & $\begin{array}{l}\text { Dragon Natu- } \\
\text { rallyspeaking, } \\
\text { Voice Finger, Via } \\
\text { Talk, Tazti } \\
\text { softwares have } \\
\text { been reported to be } \\
\text { beneficial to } \\
\text { students with } \\
\text { ADHD and } \\
\text { resulted in } \\
\text { improvement in } \\
\text { the areas of } \\
\text { writing, reading } \\
\text { and spelling [65] }\end{array}$ \\
\hline
\end{tabular}


Table 5. Cont.

\begin{tabular}{|c|c|c|c|c|c|}
\hline Author/Year & AI Tool & $\begin{array}{c}\text { Features/Model Used } \\
\text { for Training }\end{array}$ & $\begin{array}{c}\text { Type of } \\
\text { Technology }\end{array}$ & $\begin{array}{l}\text { Learning Area } \\
\text { Addressed }\end{array}$ & Effectiveness \\
\hline $2018[63,67]$ & Talking calculators & $\begin{array}{l}\text { - User's data such } \\
\text { as pressing of } \\
\text { numbers } \\
\text { - } \quad \text { Built-in speech } \\
\text { synthesiser }\end{array}$ & $\begin{array}{l}\text { Assistive } \\
\text { technology }\end{array}$ & $\begin{array}{l}\text { Helps students } \\
\text { hear and process } \\
\text { numbers easily for } \\
\text { mathematics. }\end{array}$ & $\begin{array}{l}\text { Students are able } \\
\text { to complete } \\
\text { assessments faster } \\
\text { with the help of } \\
\text { the calculator and } \\
\text { has helped } \\
\text { students gain } \\
\text { independence [67] }\end{array}$ \\
\hline
\end{tabular}

AI assistive tools used to teach students with Dyslexia.

\begin{tabular}{|c|c|c|c|c|c|}
\hline $2013[68]$ & $\begin{array}{c}\text { Intelligent } \\
\text { dyslexic system }\end{array}$ & $\begin{array}{c}\text { Machine learning } \\
\text { algorithm, } \\
\text { visualisation concept }\end{array}$ & $\begin{array}{l}\text { Assistive } \\
\text { technology }\end{array}$ & $\begin{array}{l}\text { Helps students } \\
\text { gain knowledge on } \\
\text { alphabets } \\
\text { and letters }\end{array}$ & $\begin{array}{l}\text { The technology } \\
\text { has the potential to } \\
\text { improve the } \\
\text { reading and } \\
\text { writing skills } \\
\text { of students. }\end{array}$ \\
\hline 2014 [69] & $\begin{array}{l}\text { Agent DYSL } \\
\text { adaptive } \\
\text { reading system }\end{array}$ & $\begin{array}{l}\text { Machine learning } \\
\text { algorithm, } \\
\text { Mel-frequency cepstral } \\
\text { coefficients, discrete } \\
\text { cosine transform }\end{array}$ & $\begin{array}{l}\text { Assistive } \\
\text { technology }\end{array}$ & $\begin{array}{l}\text { Enables the } \\
\text { personalisation of } \\
\text { reading } \\
\text { environment of } \\
\text { Greek students. }\end{array}$ & $\begin{array}{l}\text { Students' reading } \\
\text { pace and accuracy } \\
\text { were increased. }\end{array}$ \\
\hline $2015[70]$ & $\begin{array}{l}\text { Computer-based } \\
\text { learning model }\end{array}$ & $\begin{array}{l}\text { Machine } \\
\text { learning technique }\end{array}$ & - & $\begin{array}{l}\text { Explores the use of } \\
\text { machine learning } \\
\text { method to improve } \\
\text { effectiveness of } \\
\text { learning process. }\end{array}$ & - \\
\hline $2017[71]$ & $\begin{array}{c}\text { Applications for } \\
\text { reading and } \\
\text { writing } \\
\text { (Learning Ally, } \\
\text { Natural reader, } \\
\text { dyslexia quest, } \\
\text { sound literacy, } \\
\text { ginger page, v } \\
\text { books pdf voice } \\
\text { reader, openWeb, } \\
\text { reading intro by } \\
\text { OZ phonics, OCR } \\
\text { instantly pro, } \\
\text { MindMeister) }\end{array}$ & $\begin{array}{l}\text { Generation of audio } \\
\text { files, pytorch deep } \\
\text { convolutional } \\
\text { text-to-speech models } \\
\text { (PytorchDcTts) }\end{array}$ & Digital application & $\begin{array}{l}\text { Helps students } \\
\text { with reading and } \\
\text { writing skills. }\end{array}$ & $\begin{array}{l}\text { Audiobooks, such } \\
\text { as learning Ally, } \\
\text { has enabled } \\
\text { students to gain } \\
\text { confidence, } \\
\text { independence and } \\
\text { success [72]. }\end{array}$ \\
\hline 2018 [73] & $\begin{array}{l}\text { DIMMAND, } \\
\text { capturaTalk } \\
\text { application }\end{array}$ & - Chatbots & Digital application & $\begin{array}{l}\text { Provides tailored } \\
\text { interventions for } \\
\text { difficulties } \\
\text { encountered } \\
\text { in literacy. }\end{array}$ & $\begin{array}{l}\text { Information is } \\
\text { not available. }\end{array}$ \\
\hline $2020[74]$ & $\begin{array}{l}\text { Voice dream } \\
\text { reader, natural } \\
\text { reader, web reader }\end{array}$ & $\begin{array}{l}\text { - } \quad \text { Text, audio data } \\
\text { - } \quad \text { Voicebot }\end{array}$ & Digital application & $\begin{array}{l}\text { Helps with } \\
\text { building } \\
\text { reading skills. }\end{array}$ & $\begin{array}{l}\text { E-readers have } \\
\text { been found to } \\
\text { generally improve } \\
\text { reading speed and } \\
\text { comprehension as } \\
\text { compared to } \\
\text { reading on } \\
\text { paper [75]. }\end{array}$ \\
\hline
\end{tabular}


Table 5. Cont.

\begin{tabular}{|c|c|c|c|c|c|}
\hline Author/Year & AI Tool & $\begin{array}{l}\text { Features/Model Used } \\
\text { for Training }\end{array}$ & $\begin{array}{c}\text { Type of } \\
\text { Technology }\end{array}$ & $\begin{array}{l}\text { Learning Area } \\
\text { Addressed }\end{array}$ & Effectiveness \\
\hline $2020[76,77]$ & DytectiveU & $\begin{array}{ll}\text { - } & \text { Learning } \\
\text { patterns of } \\
\text { students } \\
\text { - } \quad \text { Support vector } \\
\text { machine } \\
\text { algorithm }\end{array}$ & Digital application & $\begin{array}{c}\text { Provides } \\
\text { personalised } \\
\text { game-based } \\
\text { exercises to } \\
\text { enhance specific } \\
\text { cognitive skills } \\
\text { related linked } \\
\text { to dyslexia. }\end{array}$ & $\begin{array}{l}\text { The DytectiveU } \\
\text { application is } \\
\text { reported to be able } \\
\text { to offer students a } \\
\text { variety of actions } \\
\text { that are helpful in } \\
\text { the learning of } \\
\text { reading and } \\
\text { writing [78]. }\end{array}$ \\
\hline 2020 [79] & $\begin{array}{c}\text { Generative } \\
\text { adversarial } \\
\text { network }\end{array}$ & $\begin{array}{c}\text { Conversion of } \\
\text { image/speech to text }\end{array}$ & $\begin{array}{l}\text { Assistive } \\
\text { technology }\end{array}$ & $\begin{array}{l}\text { Converts natural } \\
\text { language text to } \\
\text { images to aid } \\
\text { students in } \\
\text { their learning. }\end{array}$ & - \\
\hline
\end{tabular}

AI assistive tools used to teach students with ASD.

\begin{tabular}{|c|c|c|c|c|c|}
\hline $2011[80]$ & $\begin{array}{l}\text { LIFEisGAME } \\
\text { game }\end{array}$ & 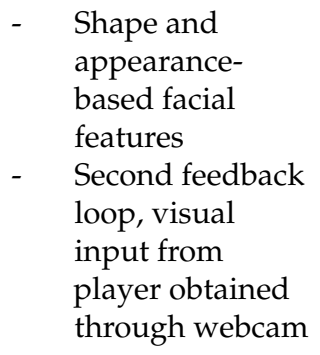 & Digital application & $\begin{array}{l}\text { To teach students } \\
\text { to recognise } \\
\text { facial emotions. }\end{array}$ & $\begin{array}{l}\text { Information is } \\
\text { not available. }\end{array}$ \\
\hline $2017[81,82]$ & $\begin{array}{l}\text { 'Empower me' } \\
\text { application }\end{array}$ & $\begin{array}{ll}\text { - } & \text { Emotion } \\
\text { recognition } \\
\text { features } \\
\text { - } \quad \text { Google } \\
\text { smartglass, } \\
\text { augmented } \\
\text { reality } \\
\text { environment, } \\
\text { web-based } \\
\text { dashboard to } \\
\text { monitor progress }\end{array}$ & $\begin{array}{l}\text { Wearable } \\
\text { technology }\end{array}$ & $\begin{array}{c}\text { Encourages social } \\
\text { interaction } \\
\text { between user and } \\
\text { peers/educators. }\end{array}$ & $\begin{array}{l}\text { Students were able } \\
\text { to improve their } \\
\text { social skills using } \\
\text { the Google glass. It } \\
\text { was also reported } \\
\text { to be fun, useful } \\
\text { and engaging [83]. }\end{array}$ \\
\hline $2018[84,85]$ & Kaspar robot & $\begin{array}{ll}\text { - } & \text { Sensory data } \\
\text { - } & \text { Reinforcement } \\
& \text { learning } \\
& \text { algorithm [86] }\end{array}$ & $\begin{array}{l}\text { Assistive } \\
\text { technology }\end{array}$ & $\begin{array}{l}\text { Helps enhance } \\
\text { social } \\
\text { interaction skills. }\end{array}$ & $\begin{array}{l}\text { The human-like } \\
\text { body and features } \\
\text { of Kaspar have } \\
\text { been reported to } \\
\text { help an ASD } \\
\text { student to be more } \\
\text { interactive [87]. }\end{array}$ \\
\hline
\end{tabular}


Table 5. Cont.

\begin{tabular}{|c|c|c|c|c|c|}
\hline Author/Year & AI Tool & $\begin{array}{c}\text { Features/Model Used } \\
\text { for Training }\end{array}$ & $\begin{array}{c}\text { Type of } \\
\text { Technology }\end{array}$ & $\begin{array}{l}\text { Learning Area } \\
\text { Addressed }\end{array}$ & Effectiveness \\
\hline 2018 [88] & $\begin{array}{l}\text { ABA flashcards- } \\
\text { Emotions, Autism } \\
\text { emotion, } \\
\text { conversation } \\
\text { builder, emotions } \\
\text { and feelings- } \\
\text { autism, Find me, } \\
\text { Kid in storybook } \\
\text { maker, learning } \\
\text { with Rufus, Look } \\
\text { in my eyes: Train } \\
\text { engineer, Model } \\
\text { me going places 2, } \\
\text { Pictello, Social } \\
\text { stories, Special } \\
\text { stories, The social } \\
\text { express, Toca Boca }\end{array}$ & 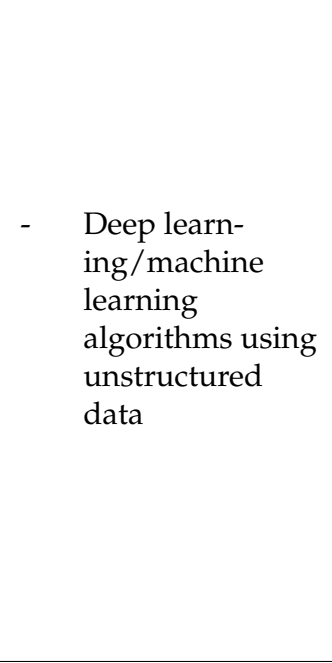 & Digital application & $\begin{array}{c}\text { Teaches } \\
\text { social skills }\end{array}$ & $\begin{array}{l}\text { Information is } \\
\text { not available. }\end{array}$ \\
\hline 2018 [88] & $\begin{array}{c}\text { ABA find it, } \\
\text { Agnitus, Autism } \\
\text { learning games- } \\
\text { camp discovery, } \\
\text { Intro to letters, } \\
\text { Intro to Math, } \\
\text { Math Bingo, Pop } \\
\text { Math, Starfall ABC, } \\
\text { Word wagon }\end{array}$ & 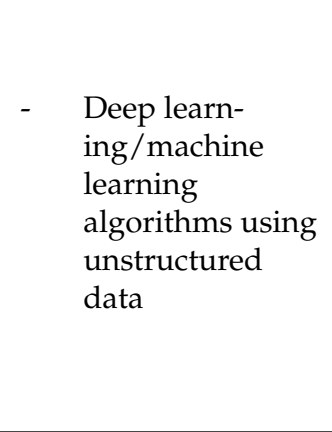 & Digital application & $\begin{array}{l}\text { Helps in different } \\
\text { learning areas }\end{array}$ & $\begin{array}{l}\text { The camp } \\
\text { discovery enabled } \\
\text { participants to } \\
\text { show high learning } \\
\text { rates over a short } \\
\text { period of time. It } \\
\text { has been suggested } \\
\text { that the } \\
\text { application teaches } \\
\text { the selected skills } \\
\text { effectively [89]. }\end{array}$ \\
\hline 2019 [90] & Emotify game & $\begin{array}{l}\text { - } \quad \begin{array}{l}\text { Audio features, } \\
\text { such as pitch of }\end{array} \\
\text { voice } \\
\text { - } \quad \text { Speech data to } \\
\text { train Random } \\
\text { forest classifier }\end{array}$ & Digital application & $\begin{array}{l}\text { Helps students to } \\
\text { recognise and } \\
\text { express feelings. }\end{array}$ & $\begin{array}{c}\text { The application } \\
\text { caused } \\
\text { participants to } \\
\text { experience more } \\
\text { engagement and } \\
\text { exhibit higher } \\
\text { behavioural } \\
\text { intentions towards } \\
\text { it [91]. }\end{array}$ \\
\hline $2019[92,93]$ & $\begin{array}{l}\text { Milo, NAO, } \\
\text { Pepper, Aisoy 1, } \\
\text { Keepon robots }\end{array}$ & $\begin{array}{l}\text { Supervised } \\
\text { machine learning } \\
\text { algorithms; } \\
\text { generalised } \\
\text { models trained } \\
\text { on users' data } \\
\text { and } \\
\text { individualised } \\
\text { models trained } \\
\text { on initial } \\
\text { subclass of users' } \\
\text { data [94] }\end{array}$ & $\begin{array}{l}\text { Assistive } \\
\text { technology }\end{array}$ & $\begin{array}{l}\text { Helps build social } \\
\text { and } \\
\text { communication } \\
\text { skills. }\end{array}$ & $\begin{array}{c}\text { Social robots, such } \\
\text { as NAO, have been } \\
\text { reported to } \\
\text { improve social } \\
\text { skills in students, } \\
\text { especially in terms } \\
\text { of eye contact and } \\
\text { concentration. } \\
\text { Nonverbal } \\
\text { children also } \\
\text { reportedly started } \\
\text { pronouncing some } \\
\text { words [95]. }\end{array}$ \\
\hline
\end{tabular}


Table 5. Cont.

\begin{tabular}{|c|c|c|c|c|c|}
\hline Author/Year & AI Tool & $\begin{array}{l}\text { Features/Model Used } \\
\text { for Training }\end{array}$ & $\begin{array}{c}\text { Type of } \\
\text { Technology }\end{array}$ & $\begin{array}{l}\text { Learning Area } \\
\text { Addressed }\end{array}$ & Effectiveness \\
\hline $2020[88,96]$ & $\begin{array}{l}\text { GoTalks speech } \\
\text { generating device, } \\
\text { AAC speech } \\
\text { buddy, } \\
\text { Proloquo2go, } \\
\text { talking Larry, } \\
\text { Touch chat HD, } \\
\text { VAST autism } \\
\text { 1-Core }\end{array}$ & $\begin{array}{ll}\text { - } & \text { Behavioural } \\
\text { features, such as } \\
\text { grabbing, } \\
\text { vocalisations } \\
\text { Deep learn- } \\
\text { ing/machine } \\
\text { learning } \\
\text { algorithms, } \\
\text { neural } \\
\text { networks [97] }\end{array}$ & $\begin{array}{c}\text { Augmentative/ } \\
\text { alternative } \\
\text { communication } \\
\text { device }\end{array}$ & $\begin{array}{l}\text { Helps with } \\
\text { building } \\
\text { communication } \\
\text { skills. }\end{array}$ & $\begin{array}{l}\text { Review studies } \\
\text { report that } \\
\text { high-technology } \\
\text { speech generating } \\
\text { devices are very } \\
\text { effective in } \\
\text { teaching manding, } \\
\text { intraverbal and } \\
\text { multistep tacting } \\
\text { to ASD } \\
\text { students [98]. }\end{array}$ \\
\hline $\begin{array}{c}2020 \\
{[96,99,100]}\end{array}$ & Facesay games & $\begin{array}{ll}\text { - } & \text { Scores on social } \\
\text { interactions } \\
\text { - } \quad \text { Facial expression } \\
\text { recognition } \\
\text { techniques, } \\
\text { interactive } \\
\text { environment } \\
\text { with lifelike } \\
\text { avatars }\end{array}$ & Digital application & $\begin{array}{l}\text { Software games } \\
\text { help recognise } \\
\text { behavioural and } \\
\text { emotional clues } \\
\text { and enhance } \\
\text { social skills. }\end{array}$ & $\begin{array}{c}\text { Facesay } \\
\text { application is } \\
\text { found to be very } \\
\text { promising, } \\
\text { cost-effective and } \\
\text { efficient for } \\
\text { teaching affect } \\
\text { recognition and } \\
\text { mentalising } \\
\text { constructs to } \\
\text { high-functioning } \\
\text { ASD } \\
\text { students [101]. }\end{array}$ \\
\hline 2020 [102] & $\begin{array}{l}\text { Personalised 'Kiwi' } \\
\text { robot for learning }\end{array}$ & 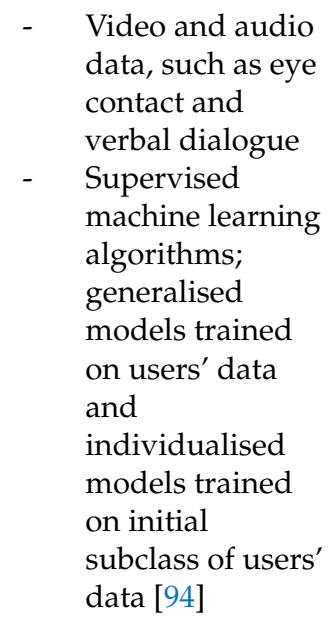 & $\begin{array}{l}\text { Assistive } \\
\text { technology }\end{array}$ & $\begin{array}{l}\text { Adapts lessons } \\
\text { according to } \\
\text { students' } \\
\text { changing needs. }\end{array}$ & $\begin{array}{l}\text { Kiwi robot has } \\
\text { been reported to } \\
\text { improve the Maths } \\
\text { skills and social } \\
\text { skills in ASD } \\
\text { students who were } \\
\text { part of the study } \\
\text { group [103]. }\end{array}$ \\
\hline 2020 [96] & $\begin{array}{l}\text { Life skills winner } \\
\text { application }\end{array}$ & $\begin{array}{l}\text { Deep learn- } \\
\text { ing/machine } \\
\text { learning } \\
\text { algorithms using } \\
\text { unstructured } \\
\text { data }\end{array}$ & Digital application & $\begin{array}{l}\text { Teaches students } \\
\text { daily living skills } \\
\text { through the } \\
\text { application. }\end{array}$ & $\begin{array}{l}\text { Information is } \\
\text { not available. }\end{array}$ \\
\hline
\end{tabular}


Table 5. Cont.

\begin{tabular}{|c|c|c|c|c|c|}
\hline Author/Year & AI Tool & $\begin{array}{c}\text { Features/Model Used } \\
\text { for Training }\end{array}$ & $\begin{array}{c}\text { Type of } \\
\text { Technology }\end{array}$ & $\begin{array}{l}\text { Learning Area } \\
\text { Addressed }\end{array}$ & Effectiveness \\
\hline 2020 [103] & PvBOT robot & $\begin{array}{l}\text { LEGO Mindstorms } \\
\text { EV3 model }\end{array}$ & $\begin{array}{l}\text { Assistive } \\
\text { technology }\end{array}$ & $\begin{array}{l}\text { Helps to teach } \\
\text { students 'place } \\
\text { value' concept in } \\
\text { Mathematics. }\end{array}$ & $\begin{array}{l}\text { PvBOT is helpful } \\
\text { in motivating } \\
\text { students to pay } \\
\text { attention and stay } \\
\text { focused for a } \\
\text { longer period. }\end{array}$ \\
\hline $2021[104]$ & $\begin{array}{c}\text { Squizzy } \\
\text { educational } \\
\text { software }\end{array}$ & Scrum methodology & $\begin{array}{l}\text { Assistive } \\
\text { technology }\end{array}$ & $\begin{array}{l}\text { Helps children stay } \\
\text { focused during } \\
\text { activities that } \\
\text { involve cognition, } \\
\text { such as colour } \\
\text { selection or } \\
\text { using pictures. }\end{array}$ & $\begin{array}{l}\text { Effective in the } \\
\text { cognitive aspect } \\
\text { of therapy. }\end{array}$ \\
\hline
\end{tabular}

\subsection{Effectiveness of AI Tools for Personalised Education}

Most AI tools that were used for learning, as shown in Table 5, have reported positive outcomes. For example, the 'Child activity sensing and training tool' for ADHD [69], which was tested in authentic situations, has been identified as having the potential to aid ADHD students in gaining attention in school settings, as well as to track their physical and physiological activities in real time [69]. Additionally, this tool has the potential to aid an ADHD student who has lost focus in his/her work. Furthermore, the 'Emotify' game developed for autistic students has obtained an accuracy of $72 \%$ in emotion recognition [83], which is a testament to its successful application. Additionally, the application has enabled participants to experience more engagement and exhibit higher behavioural intentions towards it. A study that used 'Facesay' games to aid autistic students [86] reported improvements in emotion recognition, social interaction, facial recognition, emotion recognition and social interaction in low-functioning and high-functioning autistic students. The application has also been found to be very promising, cost-effective and efficient for teaching effect recognition and mentalising constructs to high-functioning ASD students. The development of software games to help students with challenging behaviour of ADHD students has resulted in positive impacts [85] in addressing their moods, wherein a reduction in challenging behaviours of participants was reported when the games were used as an intervention to improve behaviours. Apart from the applications, the use of robots [84,85,92,93,102,103] and alternative communication devices [78,86] have been proven to be effective in improving focus, as well as math and social skills and in the teaching of ASD students, respectively. Hence, the abovementioned findings confirm the effectiveness of AI tools for personalised education.

\section{Discussion of Main Findings and Results of Study}

Figure 9, derived from Table 5 illustrates the distribution of assistive tools used to aid ADHD, dyslexia and ASD students in their learning. Figure 10, also derived from Figure 4, depicts the various assistive tools used to aid ADHD, dyslexia and ASD students in their learning. Hence, based on Figures 9 and 10, it has been established through this study that most assistive tools have been developed to support ASD students in their learning and that the most prevalently developed tools to help ADHD, dyslexia and ASD students in their learning are application-based tools. Through this review, it has also been well-established that robots and application-based tools have been developed most to support ASD students, as compared to ADHD and dyslexic students, in their learning. This is in line with an interview conducted with educators in England on humanised robots discussing optimistic views shared by some educators [69]. These educators highlighted specific cases where robots were bound to be impactful, for example as "stepping stones" to social interactions 
and the capabilities of personalised robots to meet the individual learning needs of learners with ASDs. Furthermore, educators also felt assured that the predictability and constancy of behaviour in robots would benefit learners with ASD, facilitate their learning and diminish the burdens on them [69]. The results of our review also confirm that certain AI tools have shown positive outcomes and have been successful in certain educational settings. From our review study (Table 5), it is evident that mostly application-based tools and robots have been developed to aid students with an ASD in various aspects of their learning, from developing social and communication skills to daily living skills. Furthermore, it is noticeable that more types of technology have been used and hence more AI tools have been developed to aid students with ASD as compared to other learning disabilities (Figure 10). Perhaps this may be due to the challenges in learning, social communication and play skills that individuals with ASDs face. Additionally, from the results of our review (Table 5) and extant literature, it is evident that deep learning models are used to develop robots to learn a large variety of data due to the highly heterogenous nature of ASDs [105]. Similarly, application-based tools have also been used to address the learning needs of students with dyslexia. These tools possess special features that allow individualised learning for each student. A combination of wearable devices, robots and application-based tools have been developed to aid students with ADHD. However, from the results of our review (Table 5), it has been established that not all developed tools possess special features that allow personalisation. The learning needs of a student depend on the severity and precise nature of how that disorder affects them, and thus varies from one student to another. Hence, we deduce that along with the development of AI-based assistive tools, it is imperative that special features are entrenched that allow personalisation, such that the distinctive learning need(s) of every student is met [30]. Despite its advantages, using AI to develop such tools also displays some limitations, as discussed below.
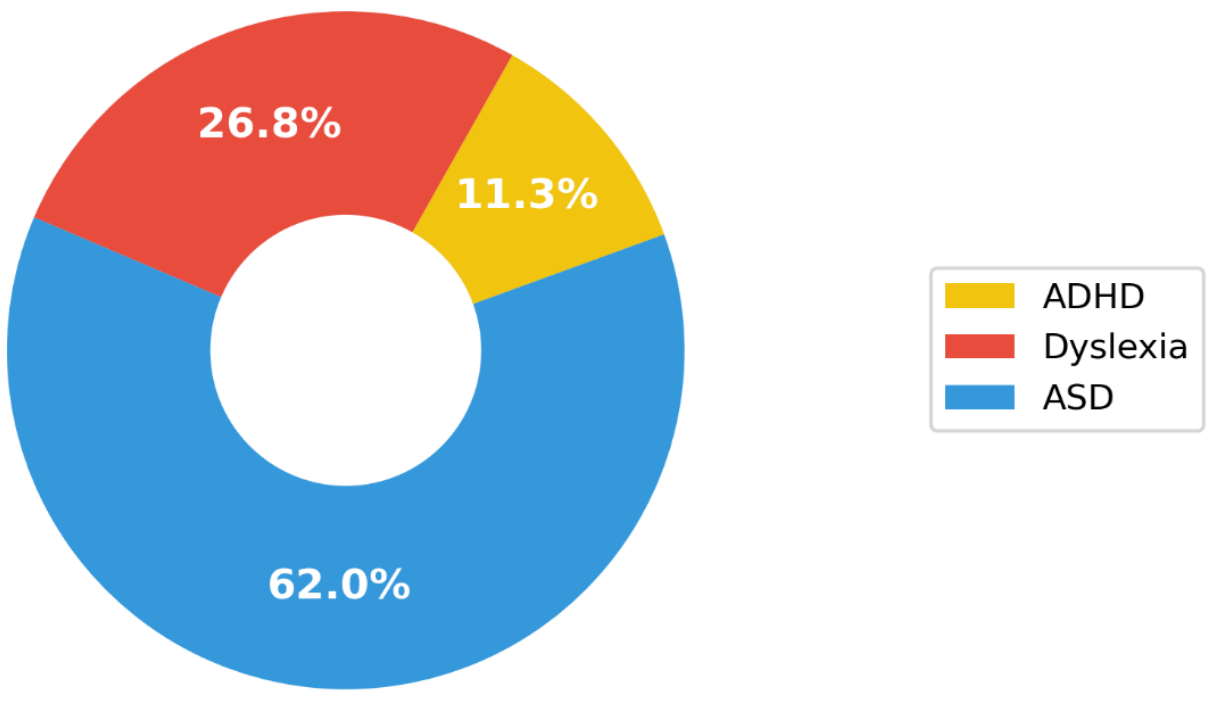

Figure 9. Pie chart representation of assistive tools used to aid in the learning of ADHD, dyslexia and ASD students.

\subsection{Limitations of Existing AI Tools for Personalised Education}

\subsubsection{Suitable Datasets}

There is a scarcity of public databases because it is challenging to obtain data from children with certain NDDs because they frequently have difficulties in staying still. There is also limited data available that focus on the severity of such disorders. Many children have complex comorbidities, so developing personalised AI tools for such students can be challenging. 


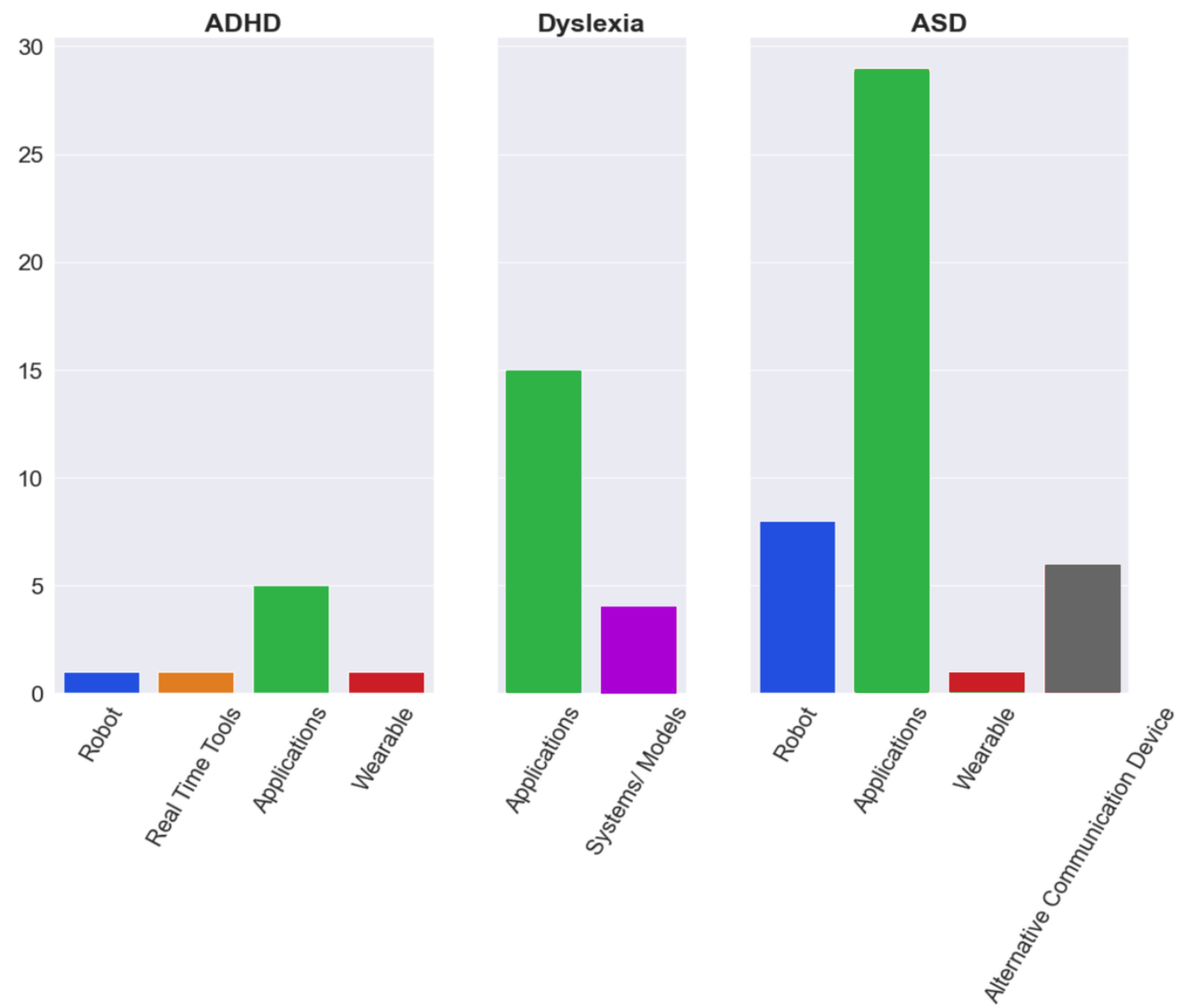

Figure 10. Bar graph representation of various assistive tools used to aid in the learning of ADHD, dyslexia and ASD students.

\subsubsection{Ethical Considerations}

There are ethical concerns about using AI-driven applications in the development of personalised tools for learning. Educational assistive technologies are commonly used with students who are adolescents; hence, ethical concerns arise over privacy, data security and informed consent, which need to be mitigated [106]. For example, the information collected about a student should be reduced to include only information necessary for the intended purpose [106], i.e., to train the machine learning model. Data collection of the student should start only once the individual knows that data collection is taking place and has consented to the data collection [106]. Most importantly, educators should also ensure that students understand the consequences of using assistive technologies to protect their privacy and data [107]. To ensure the consent is valid, the teacher could describe the potential risks and benefits in a way that does not prompt a specific decision from those individuals who may be affected by the use of the technologies [107]. Additionally, it is imperative that educational technology companies comply with the relevant regulations; for example, the Children's Online Privacy Protection Act [108] of the United States makes an attempt to determine the age of students who assess the company's applications, programmes or extensions for student data collection. If the student is below 13 years old, parental consent is required for data collection [107].

Thus, it is important that privacy considerations are respected and that student data used to train machine learning models is secure according to local ethics board requirements [109]. Safeguards need to be in place to ensure data cannot be hacked [109], and educators should ensure ethical considerations are in place before any student data is collected, when the assistive tool is being used. 


\subsubsection{Cost of Implementing AI Tools}

Besides ethical issues, Tsai and Gasevic [110] corroborate other limitations of AI in the technical (system integration) [111] and financial aspects. The costs involved in installing, maintaining and repairing AI tools is another limitation of implementing these tools in classroom settings [112]. Hence, to make AI affordable and integrate it with ease, it is imperative for schools to assimilate AI technology in a cloud-based intranet [112]. This would be more cost-effective, as schools would just need to pay an affordable subscription cost monthly, wherein various aspects, such as the installation, storage space, specifications, maintenance and technical support would be taken care of [113].

\subsubsection{Information Loss}

Another limitation is the possible loss of pertinent information when AI tools require repair [102]. Information such as students' learning data may be compromised, hampering the training of AI models or assessment of existing tools. This could be averted by adopting a cloud-based approach to safeguard information [112].

\subsection{Cloud Computing in Schools}

In recent years, cloud computing is progressively becoming popular in delivering technology in the education domain [114]. Cloud computing also allows schools to use less potent computers to assess the cloud, hence reducing computing costs [114]. However, cloud computing has potential disadvantages, and privacy, security and legal (policies) issues need to be addressed to successfully implement a cloud-based system [114].

\subsubsection{Advantages of Using AI in Cloud Computing}

The processing of information and resources, comprising the storage, sharing, backup and recovery of substantial information and resources, is a crucial aspect of AI-based technology [115]. Hence, integrating AI technology in cloud computing is beneficial as the internet and central remote servers are used to sustain information, resources and applications, resulting in effective computing as storage, processing, memory and bandwidth are centralised [115]. Similarly, backup of information can be done effortlessly by cloudbased applications, unlike traditional methods of using hard discs that are time-consuming, expensive, contain limited capacity and can require laborious maintenance [116].

Merging the AI tool in the cloud is beneficial as it is cost-saving, wherein costs related to hardware and maintenance or on-site data centres are eliminated [117]. The AI tool is also able to computerise intricate and repetitive tasks to enhance productivity and perform data analysis using intelligent automation; hence, it does not require any human intervention. The AI-based tool is also able to perform data analysis rapidly and provide deeper insights and hence is competent in offering real-time personalised recommendations to users [117]. AI tools are able to simplify how data is used, modified and handled and thus improve data management when imbedded in cloud systems. AI-powered network security tools need to be used to improve security to protect critical data when imbedded in cloud systems. Using the cloud server is also beneficial as it is part of the internet of things (IoT), where the data on shared networks [118] enables faster and more accurate outcomes. It also optimises equipment and usage of resources [118] that aid in managing situations better, such as being able to develop personalised tools for individuals. The core advantages of using cloud computing in school settings for personalised education are summarised in Figure 11, as seen below.

\subsubsection{Disadvantages of Using AI in Cloud Computing}

While AI in cloud computing may generally lower costs, a well-trained staff needs to be employed to operate the complex AI system and this may incur some cost. The cloud system would also require continuous internet connection to work well; weak internet access can impair the benefits of the cloud system [117]. Additionally, since data processing is speedier in the cloud than without using the cloud (methods discussed in Table 5), a 
time lag between transferring data to the cloud and receiving responses may be present. Privacy policies need to be complied with for data security when AI is used in cloud computing [117].

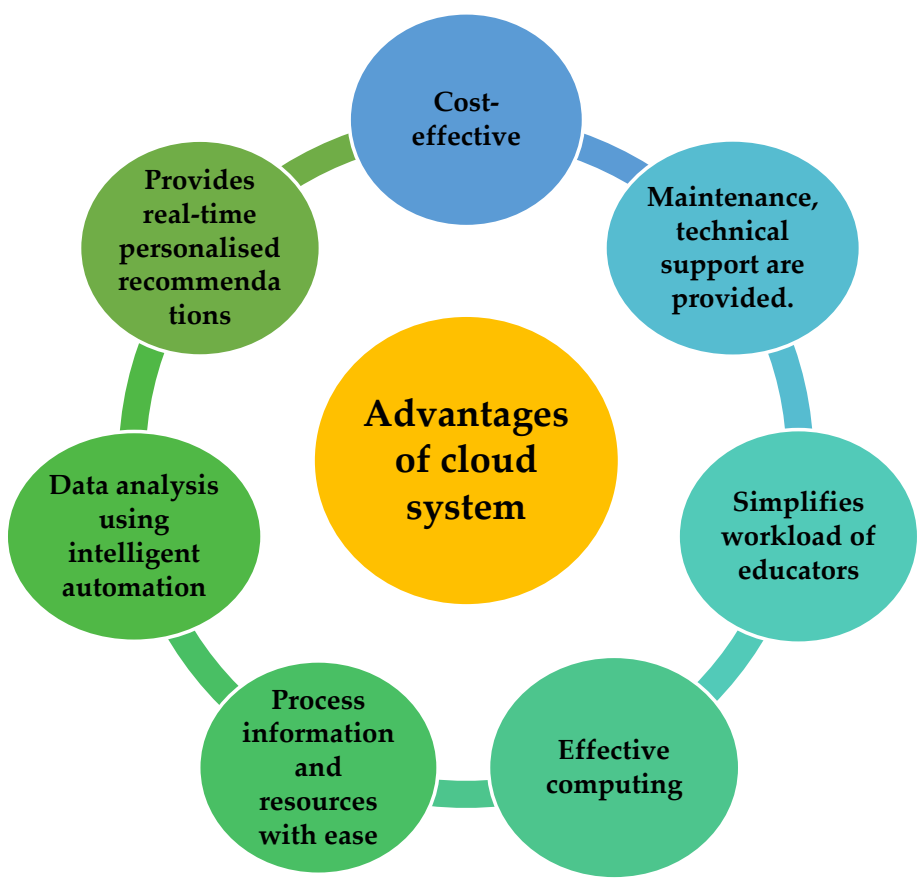

Figure 11. Benefits of using the cloud system in schools for personalised education.

Based on the discussion above, it is apparent that there are downfalls to using AI in cloud computing. For instance, as mentioned earlier, data safety and security are the major concerns of using AI tools/AI in cloud computing. To tackle cyber security issues, decentralisation should be used wherein information acquired is split into parts and stored in various parts of the network instead of storing the entire information in a central server [119]. Additionally, user privacy methods, such as including a physical layer that conceals certain measurements of users [120] or enhanced security keys that create provisional identifications [121], should be employed within the cloud system to tackle privacy issues. Ethical considerations should also be followed. Despite the limitations, it can be observed that the benefits of integrating the proposed AI tool in the cloud outweigh the limitations, especially in the development of personalised tools.

\section{Proposal for a Future AI Tool}

Presently, machine learning techniques have not been explored in cloud-based applications for personalised learning tools. Hence, in our future work, we will be using deep learning techniques to develop a unique cloud-based model or an application-based tool that enables personalisation and serves as an assistive tool for teachers or other adults who assist in learning. Sizeable data comprising input features, such as facial expression images, speech signals, bio signals and clinical information, such as age, gender, genetic history, and so on would be used to develop the personalised model. The data obtained from the individual user will be sent to the trained deep learning model, which will be kept in the cloud server. The model will then be able to predict the user's learning needs accordingly and provide personalised learning to suit the child's learning needs. The proposed tool will also have decentralisation and user privacy methods implemented in it. The proposed AI-based tool for personalised learning is shown in Figure 12. 


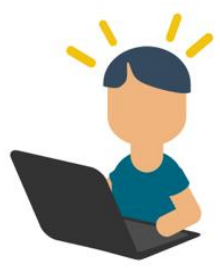

\section{Student's Personalised Learning}

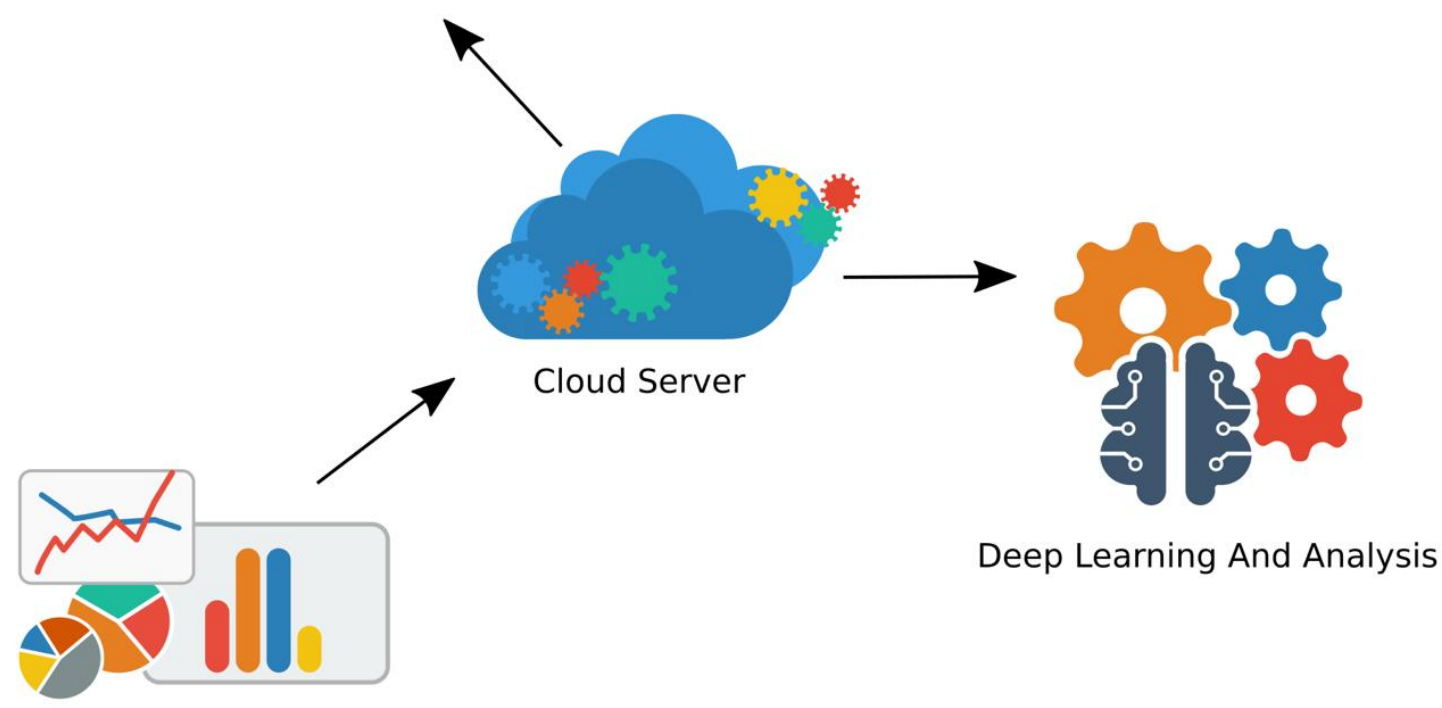

Personalised Application

Based Tool

Figure 12. Proposed AI-based tool for personalised learning.

\section{Conclusions}

This review highlights that despite being in its infancy stage, assisted tools have been proposed to address the learning needs and quality of life of children with the most common NDDs: ADHD, dyslexia and ASDs [122]. The majority of the existing works using AI have focused on ASD. It is clear that more work needs to be done on the development and evaluation of assistive technologies for children with a range of NDDs [62]. The studies done to date have shown that AI-assisted tools have shown positive impacts on student's learning, and have been found to be acceptable by teachers, parents, special educators and therapists and feasible to implement in their teaching or therapeutic practices [122]. AI techniques have been reported to assimilate the independence of user's actions and enable children with learning difficulties to achieve their individual learning goals [122]. However, as discussed previously, our review reports that the existing AI assistive tools exhibit some limitations, so more work still needs to be done to 'mainstream' such approaches and maximise their impact. For example, the AI tools reported here are not embedded in cloud systems, hence limiting their ability to provide real-time suggestions for personalised learning. AI-based tools in the cloud system, such as digital applications, could be a major advance facilitating the provision of personalised specialist education and learning for affected individuals in real time.

Author Contributions: Conceptualisation, P.D.B. and U.R.A.; methodology, E.P.; formal analysis, S.L.O. and R.G.; writing — original draft preparation, J.V.; writing—review and editing, J.V., E.P., N.A.K. and M.M.A. All authors have read and agreed to the published version of the manuscript.

Funding: This research received no external funding.

Institutional Review Board Statement: Not applicable. 


\section{Informed Consent Statement: Not applicable.}

Conflicts of Interest: The authors declare no conflict of interest. The funders had no role in the design of the study, in the collection, analyses or interpretation of data, in the writing of the manuscript, or in the decision to publish the results.

\section{References}

1. Kieling, C.; Baker-Henningham, H.; Belfer, M.; Conti, G.; Ertem, I.; Omigbodun, O.; Rohde, L.A.; Srinath, S.; Ulkuer, N.; Rahman, A. Child and adolescent mental health worldwide: Evidence for action. Lancet 2011, 378, 1515-1525. [CrossRef]

2. Jeste, S. Neurodevelopmental Behavioral and Cognitive Disorders. Contin. Lifelong Learn. Neurol. 2015, 21, 690-714. [CrossRef] [PubMed]

3. Renemane, L.; Kivite-Urtane, A.; Rancans, E. Suicidality and Its Relation with Physical and Mental Conditions: Results from a Cross-Sectional Study of the Nationwide Primary Care Population Sample in Latvia. Medicina 2021, 57, 970. [CrossRef] [PubMed]

4. Nepon, J.; Belik, S.-L.; Bolton, J.; Sareen, J. The relationship between anxiety disorders and suicide attempts: Findings from the National Epidemiologic Survey on Alcohol and Related Conditions. Depress. Anxiety 2010, 27, 791-798. [CrossRef] [PubMed]

5. Wang, Y.; Jitender, S.; Afifi, T.O.; Shay-Lee, B.; Johnson, E.A.; Bolton, J.M. Recent Stressful Life Events and Suicide Attempt. Psychiatr. Ann. 2012, 42, 101-108. [CrossRef]

6. Foley, D.L.; Goldston, D.B.; Costello, E.J.; Angold, A. Proximal Psychiatric Risk Factors for Suicidality in Youth: The Great Smoky Mountains Study. Arch. Gen. Psychiatry 2006, 63, 1017-1024. [CrossRef]

7. Oerbeck, B.; Overgaard, K.R.; Aspenes, S.T.; Pripp, A.H.; Mordre, M.; Aase, H.; Reichborn-Kjennerud, T.; Zeiner, P. ADHD, comorbid disorders and psychosocial functioning: How representative is a child cohort study? Findings from a national patient registry. BMC Psychiatry 2017, 17, 23. [CrossRef]

8. Jensen, C.M.; Steinhausen, H.-C. Comorbid mental disorders in children and adolescents with attention-deficit/hyperactivity disorder in a large nationwide study. Atten. Defic. Hyperact. Disord. 2015, 7, 27-38. [CrossRef]

9. Mattila, M.-L.; Hurtig, T.; Haapsamo, H.; Jussila, K.; Kuusikko-Gauffin, S.; Kielinen, M.; Linna, S.-L.; Ebeling, H.; Bloigu, R.; Joskitt, L.; et al. Comorbid Psychiatric Disorders Associated with Asperger Syndrome/High-functioning Autism: A Communityand Clinic-based Study. J. Autism Dev. Disord. 2010, 40, 1080-1093. [CrossRef]

10. Gjevik, E.; Eldevik, S.; Fjæran-Granum, T.; Sponheim, E. Kiddie-SADS Reveals High Rates of DSM-IV Disorders in Children and Adolescents with Autism Spectrum Disorders. J. Autism Dev. Disord. 2010, 41, 761-769. [CrossRef]

11. Yerys, B.E.; Wallace, G.; Sokoloff, J.L.; Shook, D.A.; James, J.D.; Kenworthy, L. Attention deficit/hyperactivity disorder symptoms moderate cognition and behavior in children with autism spectrum disorders. Autism Res. 2009, 2, 322-333. [CrossRef] [PubMed]

12. Hansen, B.H.; Oerbeck, B.; Skirbekk, B.; Petrovski, B.É.; Kristensen, H. Neurodevelopmental disorders: Prevalence and comorbidity in children referred to mental health services. Nord. J. Psychiatry 2018, 72, 285-291. [CrossRef] [PubMed]

13. Sheehan, R. Mental Illness in Children: Childhood Illness and Supporting the Family. Brain Sci. 2017, 7, 97. [CrossRef] [PubMed]

14. Danielson, M.; Bitsko, R.H.; Ghandour, R.M.; Holbrook, J.R.; Kogan, M.D.; Blumberg, S.J. Prevalence of Parent-Reported ADHD Diagnosis and Associated Treatment Among U.S. Children and Adolescents, 2016. J. Clin. Child Adolesc. Psychol. 2018, 47, 199-212. [CrossRef] [PubMed]

15. Akutagava-Martins, G.C.; Rohde, L.A.; Hutz, M.H. Genetics of attention-deficit/hyperactivity disorder: An update. Expert Rev. Neurother. 2016, 16, 145-156. [CrossRef]

16. Linnet, K.M.; Dalsgaard, S.; Obel, C.; Wisborg, K.; Henriksen, T.B.; Rodriguez, A.; Kotimaa, A.; Moilanen, I.; Thomsen, P.H.; Olsen, J.; et al. Maternal Lifestyle Factors in Pregnancy Risk of Attention Deficit Hyperactivity Disorder and Associated Behaviors: Review of the Current Evidence. Am. J. Psychiatry 2003, 160, 1028-1040. [CrossRef] [PubMed]

17. Levin, H.; Hanten, G.; Max, J.; Li, X.; Swank, P.; Ewing-Cobbs, L.; Dennis, M.; Menefee, D.S.; Schachar, R. Symptoms of Attention-Deficit/Hyperactivity Disorder Following Traumatic Brain Injury in Children. J. Dev. Behav. Pediatr. 2007, 28, 108-118. [CrossRef]

18. Hesdorffer, D.C.; Ludvigsson, P.; Olafsson, E.; Gudmundsson, G.; Kjartansson, O.; Hauser, W.A. ADHD as a risk factor for incident unprovoked seizures and epilepsy in children. Arch. Gen. Psychiatry 2004, 61, 731-736. [CrossRef]

19. Sridhar, C.; Bhat, S.; Acharya, U.R.; Adeli, H.; Bairy, G.M. Diagnosis of attention deficit hyperactivity disorder using imaging and signal processing techniques. Comput. Biol. Med. 2017, 88, 93-99. [CrossRef]

20. Koh, J.; Ooi, C.P.; Lim-Ashworth, N.S.; Vicnesh, J.; Tor, H.T.; Lih, O.S.; Tan, R.-S.; Acharya, U.; Fung, D.S.S. Automated classification of attention deficit hyperactivity disorder and conduct disorder using entropy features with ECG signals. Comput. Biol. Med. 2021, 140, 105120. [CrossRef]

21. Biederman, J.; Monuteaux, M.C.; Mick, E.; Spencer, T.; Wilens, T.E.; Silva, J.M.; Snyder, L.E.; Faraone, S.V. Young adult outcome of attention deficit hyperactivity disorder: A controlled 10-year follow-up study. Psychol. Med. 2006, 36, 167-179. [CrossRef]

22. DuPaul, G.J.; Gormley, M.J.; Laracy, S.D. Comorbidity of LD and ADHD: Implications of DSM-5 for Assessment and Treatment. J. Learn. Disabil. 2013, 46, 43-51. [CrossRef] [PubMed]

23. Snowling, M.J.; Gooch, D.C.; Henderson, L.M. Dyslexia. In Encyclopedia of Human Behavior, 2nd ed.; Ramachandran, Ed.; Academic Press: San Diego, CA, USA, 2012; pp. 732-739. 
24. Tsampalas, E.; Dimitrios, S.; Papadimitropoulou, P.; Vergou, M.; Zakopoulou, V. Learning Paths and Learning Styles in Dyslexia: Possibilites and Effectiveness-Case Study of Two Elementary School Students Aged 7 Years Old. Eur. J. Spec. Educ. Res. 2018, 3 , 25-41.

25. Perrachione, T.K.; Del Tufo, S.; Winter, R.; Murtagh, J.; Cyr, A.; Chang, P.; Halverson, K.; Ghosh, S.; Christodoulou, J.A.; Gabrieli, J.D. Dysfunction of Rapid Neural Adaptation in Dyslexia. Neuron 2016, 92, 1383-1397. [CrossRef] [PubMed]

26. Kopp, S.; Gillberg, C. Swedish child and adolescent psychiatric out-patients: A five-year cohort. Eur. Child Adolesc. Psychiatry 2003, 12, 30-35. [CrossRef]

27. Baygin, M.; Dogan, S.; Tuncer, T.; Barua, P.D.; Faust, O.; Arunkumar, N.; Abdulhay, E.W.; Palmer, E.E.; Acharya, U.R. Automated ASD detection using hybrid deep lightweight features extracted from EEG signals. Comput. Biol. Med. 2021, $134,104548$. [CrossRef]

28. Khodatars, M.; Shoeibi, A.; Sadeghi, D.; Ghaasemi, N.; Jafari, M.; Moridian, P.; Khadem, A.; Alizadehsani, R.; Zare, A.; Kong, Y.; et al. Deep learning for neuroimaging-based diagnosis and rehabilitation of Autism Spectrum Disorder: A review. Comput. Biol. Med. 2021, 139, 104949. [CrossRef]

29. Tang, G.; Gudsnuk, K.; Kuo, S.-H.; Cotrina, M.L.; Rosoklija, G.; Sosunov, A.; Sonders, M.S.; Kanter, E.; Castagna, C.; Yamamoto, A.; et al. Loss of mTOR-Dependent Macroautophagy Causes Autistic-like Synaptic Pruning Deficits. Neuron 2014, 83, 1131-1143. [CrossRef]

30. Sharif, H.; Khan, R.A. A novel framework for automatic detection of Autism: A study on Corpus Callosum and Intracranial Brain Volume. arXiv 2019.

31. Yoro, A.J.; Fourie, J.V.; Van Der Merwe, M. Learning support strategies for learners with neurodevelopmental disorders: Perspectives of recently qualified teachers. Afr. J. Disabil. 2020, 9, 561. [CrossRef] [PubMed]

32. Richa, S.; Fahed, M.; Khoury, E.; Mishara, B. Suicide in Autism Spectrum Disorders. Arch. Suicide Res. 2014, 18, 327-339. [CrossRef]

33. Ewe, L.P. ADHD symptoms and the teacher-student relationship: A systematic literature review. Emot. Behav. Diffic. 2018, 24, 136-155. [CrossRef]

34. Henricsson, L.; Rydell, A.-M. Elementary School Children with Behavior Problems: Teacher-Child Relations and Self-Perception. A Prospective Study. Merrill-Palmer Q. 2004, 50, 111-138. [CrossRef]

35. Gwernan-Jones, R.; Moore, D.A.; Cooper, P.; Russell, A.E.; Richardson, M.; Rogers, M.; Thompson-Coon, J.; Stein, K.; Ford, T.J.; Garside, R. A systematic review and synthesis of qualitative research: The influence of school context on symptoms of attention deficit hyperactivity disorder. Emot. Behav. Diffic. 2016, 21, 83-100. [CrossRef]

36. Teaching Children With Attention Deficit Hyperactivity Disorder: Instructional Strategies and Practices; US Department of Education Office of Special Education and Rehabilitative Services: Washington, DC, USA, 2006.

37. Hanover Research. Best Practices in Personalized Learning; Hanover Research: Washington, DC, USA, 2006, 2012 ; pp. 4-41.

38. Hume, K. Visual Structure in the School Setting; Indiana Resource Centre for Asutism; Indiana University: Bloomington, IN, USA, 2011.

39. Hoque, M.E. Analysis of speech properties of neurotypicals and individuals diagnosed with autism and down syndrome. In Proceedings of the ASSETS'08: The 10th International ACM SIGACCESS Conference on Computers and Accessibility, Halifax, NS, Canada, 13-15 October 2008.

40. Siam, K.; Al-Natour, M. Teacher's Differentiated Instruction Practices and Implementation Challenges for Learning Disabilities in Jordan. Int. Educ. Stud. 2016, 9, 167. [CrossRef]

41. Pham, T.-H.; Vicnesh, J.; Wei, J.K.E.; Oh, S.L.; Arunkumar, N.; Abdulhay, E.W.; Ciaccio, E.J.; Acharya, U.R. Autism Spectrum Disorder Diagnostic System Using HOS Bispectrum with EEG Signals. Int. J. Environ. Res. Public Heal. 2020, 17, 971. [CrossRef]

42. Oh, S.L.; Jahmunah, V.; Arunkumar, N.; Abdulhay, E.W.; Gururajan, R.; Adib, N.; Ciaccio, E.J.; Cheong, K.H.; Acharya, U.R. A novel automated autism spectrum disorder detection system. Complex Intell. Syst. 2021, 7, 2399-2413. [CrossRef]

43. Dubreuil-Vall, L.; Ruffini, G.; Camprodon, J.A. Deep Learning Convolutional Neural Networks Discriminate Adult ADHD From Healthy Individuals on the Basis of Event-Related Spectral EEG. Front. Neurosci. 2020, 14, 1-12. [CrossRef] [PubMed]

44. Tor, H.T.; Ooi, C.P.; Lim-Ashworth, N.S.; Wei, J.K.E.; Jahmunah, V.; Oh, S.L.; Acharya, U.R.; Fung, D.S.S. Automated detection of conduct disorder and attention deficit hyperactivity disorder using decomposition and nonlinear techniques with EEG signals. Comput. Methods Programs Biomed. 2021, 200, 105941. [CrossRef]

45. Acharya, U.R.; Oh, S.L.; Hagiwara, Y.; Tan, J.H.; Adeli, H.; Subha, D.P. Automated EEG-based screening of depression using deep convolutional neural network. Comput. Methods Programs Biomed. 2018, 161, 103-113. [CrossRef]

46. He, L.; Cao, C. Automated depression analysis using convolutional neural networks from speech. J. Biomed. Inform. 2018, 83, 103-111. [CrossRef]

47. Detecting Depression Using a Framework Combining Deep Multimodal Neural Networks with a Purpose-Built Automated Evaluation. Psychol. Assess. 2019, 31, 1019. [CrossRef]

48. Indolia, S.; Goswami, A.; Mishra, S.; Asopa, P. Conceptual Understanding of Convolutional Neural Network-A Deep Learning Approach. Procedia Comput. Sci. 2018, 132, 679-688. [CrossRef]

49. Lih, O.S.; Jahmunah, V.; San, T.R.; Ciaccio, E.J.; Yamakawa, T.; Tanabe, M.; Kobayashi, M.; Faust, O.; Acharya, U.R. Comprehensive electrocardiographic diagnosis based on deep learning. Artif. Intell. Med. 2020, 103, 101789. [CrossRef]

50. Oh, S.L.; Vicnesh, J.; Ciaccio, E.J.; Yuvaraj, R.; Acharya, U.R. Deep Convolutional Neural Network Model for Automated Diagnosis of Schizophrenia Using EEG Signals. Appl. Sci. 2019, 9, 2870. [CrossRef] 
51. Cascade, R.; Chunking, N.S. Long Short-Term Memory. Neural Comput. 1997, 9, 1735-1780.

52. Hinton, G.E.; Salakhutdinov, R.R. Reducing the Dimensionality of Data with Neural Networks. Science 2006, 313, 504-507. [CrossRef] [PubMed]

53. Belpaeme, T.; Baxter, P.E.; Read, R.; Wood, R.; Cuayáhuitl, H.; Kiefer, B.; Racioppa, S.; Kruijff-Korbayová, I.; Athanasopoulos, G.; Enescu, V.; et al. Multimodal Child-Robot Interaction: Building Social Bonds. J. Hum. Robot Interact. 2013, 1, 33-53. [CrossRef]

54. Sanghvi, J.; Castellano, G.; Leite, I.; Pereira, A.; McOwan, P.W.; Paiva, A. Automatic analysis of affective postures and body motion to detect engagement with a game companion. In Proceedings of the 6 th International Conference on Human-Robot Interaction-HRI '11, Lausanne, Switzerland, 6-9 March 2011; pp. 305-312.

55. Kim, J.C.; Azzi, P.; Jeon, M.; Howard, A.M.; Park, C.H. Audio-based emotion estimation for interactive robotic therapy for children with autism spectrum disorder. In Proceedings of the 2017 14th International Conference on Ubiquitous Robots and Ambient Intelligence (URAI), Jeju, Korea, 28 June-1 July 2017; pp. 39-44.

56. Anzalone, S.M.; Boucenna, S.; Ivaldi, S.; Chetouani, M. Evaluating the Engagement with Social Robots. Int. J. Soc. Robot. 2015, 7 , 465-478. [CrossRef]

57. Colton, M.B.; Ricks, D.J.; Goodrich, M.A.; Dariush, B.; Fujimura, K.; Fujiki, M. Toward therapist-in-the-loop assistive robotics for children with autism and specific language impairment. In Proceedings of the 23rd Convention of the Society for the Study of Artificial Intelligence and Simulation of Behaviour, AISB 2009, Edinburgh, UK, 6-9 April 2009.

58. Hernandez, J.; Riobo, I.; Rozga, A.; Abowd, G.D.; Picard, R.W. Using electrodermal activity to recognize ease of engagement in children during social interactions. In Proceedings of the 2014 ACM International Joint Conference on Pervasive and Ubiquitous Computing, Seattle, WA, USA, 13-17 September 2014; pp. 307-317.

59. Esteban, P.G.; Baxter, P.; Belpaeme, T.; Billing, E.; Cai, H.; Cao, H.-L.; Coeckelbergh, M.; Costescu, C.; David, D.; De Beir, A.; et al. How to Build a Supervised Autonomous System for Robot-Enhanced Therapy for Children with Autism Spectrum Disorder. Paladyn J. Behav. Robot. 2017, 8, 18-38. [CrossRef]

60. Rudovic, O.; Lee, J.; Dai, M.; Schuller, B.; Picard, R.W. Personalized machine learning for robot perception of affect and engagement in autism therapy. Sci. Robot. 2018, 3, eaao6760. [CrossRef] [PubMed]

61. Fridin, M. Storytelling by a kindergarten social assistive robot: A tool for constructive learning in preschool education. Comput. Educ. 2014, 70, 53-64. [CrossRef]

62. Sonne, T.; Obel, C.; Grønbæk, K. Designing real time assistive technologies: A study of children with ADHD. In Proceedings of the Annual Meeting of the Australian Special Interest Group for Computer Human Interaction, Parkville, VIC, Australia, 7-10 December 2015; pp. 34-38.

63. Lynch, M. Assistive techology to help children with attention deficit hyperactivity disorder succeed academically. Assitive Technology, 9 May 2018.

64. Somma, F.; Rega, A.; Gigliotta, O. Artificial Intelligence-powered cognitive training applications for children with attention deficit hyperactivity disorder: A brief review. Child. Worldw. 2019, 2, 4.

65. Lopresti, E. Rehabilitation and Prosthetic Services; Device Review: Watchminder by Watchminder; 2015. Available online: https:/ / www.prosthetics.va.gov / AssistiveTechnology/reviews/Device_Review_WatchMinder.asp (accessed on 25 February 2021).

66. Huang, X.; Baker, J.; Reddy, R. A historical perspective of speech recognition. Commun. ACM 2014, 57, 94-103. [CrossRef]

67. Bouck, E.C.; Flanagan, S.; Joshi, G.S.; Sheikh, W.; Schleppenbach, D. Speaking Math-A Voice Input, Speech Output Calculator for Students with Visual Impairments. J. Spéc. Educ. Technol. 2011, 26, 1-14. [CrossRef]

68. Ndombo, M.; Ojo, S.; Osunmakinde, I. An intelligent integrative assistive system for dyslexic learners. J. Assist. Technol. 2013, 7 , 172-187. [CrossRef]

69. Athanaselis, T.; Bakamidis, S.; Dologlou, I.; Argyriou, E.N.; Symvonis, A. Making assistive reading tools user friendly: A new platform for Greek dyslexic students empowered by automatic speech recognition. Multimedia Tools Appl. 2014, 68, 681-699. [CrossRef]

70. Hamid, S.S.A.; Admodisastro, N.; Kamaruddin, A. A study of computer-based learning model for students with dyslexia. In Proceedings of the 2015 9th Malaysian Software Engineering Conference (MySEC), Kuala Lumpur, Malaysia, 16-17 December 2015; pp. 284-289.

71. Lynch, M. 11 Must-Have Apps and Tools for Dyslexic Students. Available online: https:/ /gokicker.com/dyslexia-tools / (accessed on 18 October 2021)

72. Michalos, A.C. Encyclopedia of Quality of Life and Well-Being Research; Springer: Dordrecht, The Netherlands, $2014 ;$ p. 5736.

73. Sood, M.R.; Toornstra, A.; Sereno, M.I.; Boland, M.; Filaretti, D.; Sood, A. A Digital App to Aid Detection, Monitoring, and Management of Dyslexia in Young Children (DIMMAND): Protocol for a Digital Health and Education Solution. JMIR Res. Protoc. 2018, 7, e135. [CrossRef]

74. World's First App Screens for Dyslexia in Minutes Using Artificial Intelligence. 2020. Available online: https://dystech.com.au/ education/worlds-first-app-screens-for-dyslexia-in-minutes-using-artificial-intelligence/ (accessed on 24 August 2021).

75. Schneps, M.H.; Thomson, J.M.; Chen, C.; Sonnert, G.; Pomplun, M. E-Readers Are More Effective than Paper for Some with Dyslexia. PLoS ONE 2013, 8, e75634. [CrossRef] 
76. Spanish Application Using AI to Overcome Dyslexia Wins 2019 UNESCO ICT Prize. UNESCO, 2020. Available online: https:/ / en.unesco.org/news/spanish-application-using-ai-help-overcome-dyslexia-wins-2019-unesco-ict-prize (accessed on 24 August 2021).

77. Rello, L.K.; Williams, A.; Ali, N.C.; White, J.P. Bigham, Dytective: Towards Detecting Dyslexia across Languages Using an Online Game. In Proceedings of the 13th International Web for All Conference, Montreal, QC, Canada, 11-13 April 2016.

78. Agama, A.A.; Gómez, R.M. DytectiveU application: Contribution to the literacy in children with dyslexia. Espirales Rev. Multidiscip. De Investig. 2021, 5, 27-35. [CrossRef]

79. Shukla, R.; Bhattacharyya, B.; Nadu, T.; Agarwal, R.; Nadu, T. A Comprehensive Study of Audio Visual Aids for Dyslexic Children. IJEET 2020, 11, 211-218.

80. Abirached, B.; Zhang, Y.; Aggarwal, J.K.; Tamersoy, B.; Fernandes, T.; Carlos, J. Improving communication skills of children with ASDs through interaction with virtual characters. In Proceedings of the 2011 IEEE 1st International Conference on Serious Games and Applications for Health (SeGAH), Braga, Portugal, 16-18 November 2011; pp. 1-4. [CrossRef]

81. Brain Power, L.L.C. Brain Power Releases First Augmented Reality Smartglasses to Help People with Autism Increase Social, School, and Job Success. Business Wire (English). 11AD. Available online: https://www.businesswire.com/news/home/2017 1107006113/en/Brain-Power-Releases-First-Augmented-Reality-Smartglasses-to-Help-People-with-Autism-Increase-SocialSchool-and-Job-Success (accessed on 7 December 2021).

82. Fernandez, M. This Emotionally Intelligent Device Is Helping Kids with Autism Form Bonds. Health, 21 March 2018.

83. Google Glass Helps Kids with Autism Read Facial Expressions. Stanford Medicine. 2018. Available online: https: //med.stanford.edu/news/all-news/2018/08/google-glass-helps-kids-with-autism-read-facial-expressions.html (accessed on 24 February 2021).

84. Miller, B. How Kaspar the Robot Is Helping Autistic Students to Socialise. News, 5 June 2018.

85. Wood, L.J.; Zaraki, A.; Robins, B.; Dautenhahn, K. Developing Kaspar: A Humanoid Robot for Children with Autism. Int. J. Soc. Robot. 2021, 13, 491-508. [CrossRef] [PubMed]

86. Zaraki, A.; Khamassi, M.; Wood, L.; Lakatos, G.; Tzafestas, C.; Amirabdolahian, F.; Robins, B.; Dautenhahn, K. A Novel Reinforcement-Based Paradigm for Children to Teach the Humanoid Kaspar Robot. Int. J. Soc. Robot. 2019, 12, 709-720. [CrossRef]

87. Papakostas, G.; Sidiropoulos, G.; Papadopoulou, C.; Vrochidou, E.; Kaburlasos, V.; Papadopoulou, M.; Holeva, V.; Nikopoulou, V.-A.; Dalivigkas, N. Social Robots in Special Education: A Systematic Review. Electronics 2021, $10,1398$. [CrossRef]

88. Enabling Devices. Apps for Individuals on the Autism Spectrum. 2019, pp. 1-16. Available online: https://enablingdevices.com/ wp-content/uploads / 2019/03/Apps-for-Individuals-with-Autism.pdf (accessed on 7 December 2021).

89. Novack, M.N.; Hong, E.; Dixon, D.R.; Granpeesheh, D. An Evaluation of a Mobile Application Designed to Teach Receptive Language Skills to Children with Autism Spectrum Disorder. Behav. Anal. Pract. 2019, 12, 66-77. [CrossRef] [PubMed]

90. Rouhi, A.; Spitale, M.; Catania, F.; Cosentino, G.; Gelsomini, M.; Garzotto, F. Emotify: Emotional game for children with autism spectrum disorder based-on machine learning. In Proceedings of the 24th International Conference on Intelligent User Interfaces: Companion, Marina del Ray, CA, USA, 16-20 March 2019; pp. 31-32.

91. Wang, X.; Goh, D.H.-L.; Lim, E.-P.; Vu, A.W.L.; Chua, A.Y.K. Examining the Effectiveness of Gamification in Human Computation. Int. J. Hum.-Comput. Interact. 2017, 33, 813-821. [CrossRef]

92. Alcorn, A.M.; Ainger, E.; Charisi, V.; Mantinioti, S.; Petrović, S.; Schadenberg, B.R.; Tavassoli, T.; Pellicano, E. Educators' Views on Using Humanoid Robots with Autistic Learners in Special Education Settings in England. Front. Robot. AI 2019, 6. [CrossRef] [PubMed]

93. Study Proves AI Robots Can Boost Social Skills in Children on Autism Spectrum. Big Data Made Simple. 2020. Available online: https://bigdata-madesimple.com/ai-robots-boost-social-skills-children-autism-spectrum/ (accessed on 7 December 2021).

94. Jain, S.; Thiagarajan, B.; Shi, Z.; Clabaugh, C.; Matarić, M.J. Modeling engagement in long-term, in-home socially assistive robot interventions for children with autism spectrum disorders. Sci. Robot. 2020, 5, 1-10. [CrossRef]

95. Rakhymbayeva, N.; Seitkazina, N.; Turabayev, D.; Pak, A.; Sandygulova, A. A Long-term Study of Robot-Assisted Therapy for Children with Severe Autism and ADHD. In Proceedings of the Companion of the 2020 ACM/IEEE International Conference on Human-Robot Interaction, Cambridge, UK, 23-26 March 2020; pp. 401-402. [CrossRef]

96. Autism Spectrum Disorders (ASD): Common Assistive Technologies. 2020. Available online: https://guides.library.illinois.edu/ c.php?g=515793\&p=3526329 (accessed on 25 February 2021).

97. Elsahar, Y.; Hu, S.; Bouazza-Marouf, K.; Kerr, D.; Mansor, A. Augmentative and Alternative Communication (AAC) Advances: A Review of Configurations for Individuals with a Speech Disability. Sensors 2019, 19, 1911. [CrossRef]

98. Muharib, R.; Alzrayer, N.M. The Use of High-Tech Speech-Generating Devices as an Evidence-Based Practice for Children with Autism Spectrum Disorders: A Meta-analysis. Rev. J. Autism Dev. Disord. 2018, 5, 43-57. [CrossRef]

99. Muharib, R.; Correa, V.I.; Wood, C.L.; Haughney, K.L. Effects of Functional Communication Training Using GoTalk NowTM iPad®Application on Challenging Behavior of Children With Autism Spectrum Disorder. J. Spéc. Educ. Technol. 2019, 34, 71-79. [CrossRef]

100. Hopkins, I.M.; Gower, M.W.; Perez, T.A.; Smith, D.S.; Amthor, F.R.; Wimsatt, F.C.; Biasini, F.J. Avatar Assistant: Improving Social Skills in Students with an ASD Through a Computer-Based Intervention. J. Autism Dev. Disord. 2011, 41, 1543-1555. [CrossRef] [PubMed] 
101. Rice, L.M.; Wall, C.A.; Fogel, A.; Shic, F. Computer-Assisted Face Processing Instruction Improves Emotion Recognition, Mentalizing, and Social Skills in Students with ASD. J. Autism Dev. Disord. 2015, 45, 2176-2186. [CrossRef] [PubMed]

102. Macaulay, T. Robot Uses AI to Personalize Teaching of Autistic Children. Neural Human-Centric News and Analysis. 2020. Available online: https://thenextweb.com/news/robot-uses-ai-to-personalize-teaching-of-autistic-children (accessed on 24 February 2021).

103. Arshad, N.I.; Hashim, A.S.; Ariffin, M.M.; Aszemi, N.M.; Low, H.M.; Norman, A.A.; Min, L.H. Robots as Assistive Technology Tools to Enhance Cognitive Abilities and Foster Valuable Learning Experiences among Young Children With Autism Spectrum Disorder. IEEE Access 2020, 8, 116279-116291. [CrossRef]

104. Purnama, Y.; Herman, F.A.; Hartono, J.; Neilsen; Suryani, D.; Sanjaya, G. Educational Software as Assistive Technologies for Children with Autism Spectrum Disorder. Procedia Comput. Sci. 2021, 179, 6-16. [CrossRef]

105. Ham, B. Personalized 'deep learning' equips robots for autism therapy. MIT News. 2018. Available online: https:/ /news.mit. edu/2018/personalized-deep-learning-equips-robots-autism-therapy-0627 (accessed on 7 December 2021).

106. Regan, P.M.; Jesse, J. Ethical challenges of edtech, big data and personalized learning: Twenty-first century student sorting and tracking. Ethic-Inf. Technol. 2019, 21, 167-179. [CrossRef]

107. Kourtney, K. Chapter 1: Ethical Considerations When Using Artificial Intelligence-Based Assistive Technologies in Education 2021. Available online: https://openeducationalberta.ca/educationaltechnologyethics/chapter/ethical-considerations-whenusing-artificial-intelligence-based-assistive-technologies-in-education/ (accessed on 25 February 2021).

108. Smith, S.W.; Bourgeois, D.T.; James, L.; Mortati, J. The Ethical and Legal Implications of Information Systems; 2021. Available online: https:/ / bus206.pressbooks.com/chapter/chapter-12-the-ethical-and-legal-implications-of-information-systems / (accessed on 25 February 2021).

109. Paul, Y.; Hickok, E.; Sinha, A.; Tiwari, U. Artificial Intelligence in the Healthcare Industry in India; The Centre for Internet and Society: Bengaluru, India, 2018.

110. Tsai, Y.S.; Gasevic, D. Learning analytics in higher education-Challenges and policies: A review of eight learning analytics policies. In Proceedings of the Seventh International Learning Analytics \& Knowledge Conference, Vancouver, BC, Canada, 13-17 March 2017; pp. 233-242.

111. Zilvinskis, J.; Wills, J., III. Learning Analytics in Higher Education: A Reflection. InSight A J. Sch. Teach. 2019, 14, 43-54. [CrossRef]

112. 15 Pros and 6 Cons of Artificial Intelligence in the Classroom. 2021. Available online: https://livetilesglobal.com/pros-consartificial-intelligence-classroom/ (accessed on 24 February 2021).

113. Cloud-Based Intranet vs. On-Premise Intranet: Which Is Best? Available online: https://www.bizportals365.com/blog/cloudintranet-vs-on-premise-intranet/ (accessed on 24 February 2021).

114. Shi, Y.; Yang, H.H.; Yang, Z.; Wu, D. Trends of Cloud Computing in Education. Lect. Notes Comput. Sci. 2014, 116-128. [CrossRef]

115. Yang, H.H.; Yuen, S.C.Y. Handbook of Research on Practices and Outcomes in E-Learning: Issues and Trends; Hershey: New York, NY, USA, 2009; pp. 1-557.

116. Hastings, R. Researching, Evaluating, and Choosing a Backup Service in the Cloud. Comput. Libr. 2012, 32, 68-71.

117. Kanjilal, J. Benefits and Drawbacks of AI in Cloud Computing. 2021. Available online: https:// searchcloudcomputing.techtarget. $\mathrm{com} /$ tip/Benefits-and-drawbacks-of-AI-in-cloud-computing (accessed on 8 July 2020).

118. Jørgensen, F.A. The Internet of Things. A New Companion to Digit. Humanit 2015, 2012, 42-53.

119. Bansal, P.; Panchal, R.; Bassi, S.; Kumar, A. Blockchain for Cybersecurity: A Comprehensive Survey. In Proceedings of the 2020 IEEE 9th International Conference on Communication Systems and Network Technologies (CSNT), Gwalior, India, 10-12 April 2020; pp. 260-265.

120. Taha, S.; Shen, X. A Physical-Layer Location Privacy-Preserving Scheme for Mobile Public Hotspots in NEMO-Based VANETs. IEEE Trans. Intell. Transp. Syst. 2013, 14, 1665-1680. [CrossRef]

121. Han, J.; Susilo, W.; Mu, Y.; Yan, J. 2z5zcd 99psxpw. IEEE Trans. Parallel Distrib. Syst. 2012, 23, 2150-2162. [CrossRef]

122. Drigas, A.S.; Ioannidou, R.-E. A Review on Artificial Intelligence in Special Education. Commun. Comput. Inf. Sci. 2013, 278, 385-391. [CrossRef] 